\title{
THE RAPAKIVI GRANITE PLUTONS OF BODOM AND OBBNÄS, SOUTHERN FINLAND: PETROGRAPHY AND GEOCHEMISTRY
}

\author{
PAULA KOSUNEN
}

KOSUNEN, PAULA 1999. The rapakivi granite plutons of Bodom and Obbnäs, southern Finland: petrography and geochemistry. Bulletin of the Geological Society of Finland 71, Part 2, 275-304.

The Obbnäs and Bodom granite plutons of southernmost Finland show the typical petrographic and geochemical features of the Proterozoic rapakivi granites in Finland and elsewhere: they cut sharply across the $1900 \mathrm{Ma}$ Svecofennian metamorphic bedrock and have the geochemical characteristics of subalkaline A-type granites. The Bodom pluton is composed of porphyritic granites (hornblende-, hornblende-biotite-, and biotite-bearing varieties) and an evengrained granite that probably represent two separate intrusive phases. This lithologic variation does not occur in the Obbnäs pluton, which is almost entirely composed of porphyritic hornblende-biotite granite that gradually becomes more mafic to the southwest. Three types of hybrid granitoids resulting from magma mingling and mixing occur on the southwestern tip of the Obbnäs peninsula. The Bodom granites are syenogranites, whereas the composition of the Obbnäs granite varies from syeno- to monzogranite. The main silicates of both the Bodom and Obbnäs granites are quartz, microcline, plagioclase $\left(\mathrm{An}_{15-41}\right)$, biotite (siderophyllite), and generally also amphibole (ferropargasite or hastingsite). Plagioclase-mantled alkali feldspar megacrysts are absent or rare. The accessory minerals are fluorite, allanite, zircon, apatite, and iron-titanium oxides; the Obbnäs granite also contains titanite. The Bodom and Obbnäs granites are metaluminous to weakly peraluminous, with average A/CNK of 1.00 and 1.05 , respectively, have high $\mathrm{Fe} / \mathrm{Mg}$ (average $\mathrm{FeO}_{\text {tot }} /\left[\mathrm{FeO}_{\text {tot }}+\mathrm{MgO}\right]$ is 0.94 for the Bodom and 0.87 for the Obbnäs granites), and high $\mathrm{Ga} / \mathrm{Al}$ ( 3.78 to 5.22 in Bodom and 2.46 to 4.18 in Obbnäs). The REE contents are high with LREE-enriched chondrite-normalized patterns and moderate (Obbnäs) to relatively strong (Bodom) negative Eu-anomalies. The Obbnäs granite is enriched in $\mathrm{CaO}, \mathrm{TiO}_{2}, \mathrm{MgO}$, and $\mathrm{FeO}$, and depleted in $\mathrm{SiO}_{2}$ and $\mathrm{K}_{2} \mathrm{O}$ compared to the Bodom granites. Also, there are differences in the $\mathrm{Ba}, \mathrm{Rb}$, and $\mathrm{Sr}$ contents of the two plutons ( $\mathrm{Ba}$ and $\mathrm{Sr}$ higher, $\mathrm{Rb}$ lower in Obbnäs) that cannot easily be traced to single parental granite magma. These features, together with the presence of titanite in the Obbnäs pluton, suggest different sources for the granites of the two plutons: a potassium feldspar-rich source for Bodom and potassium feldspar-poor for Obbnäs.

Key words: granites, rapakivi, plutons, petrography, geochemistry, Proterozoic, Bodom, Obbnäs, Finland.

Paula Kosunen: Department of Geology, P.O. Box 11, FIN-00014 University of Helsinki, Finland

E-mail: paula.kosunen@helsinki.fi 
$1 a$

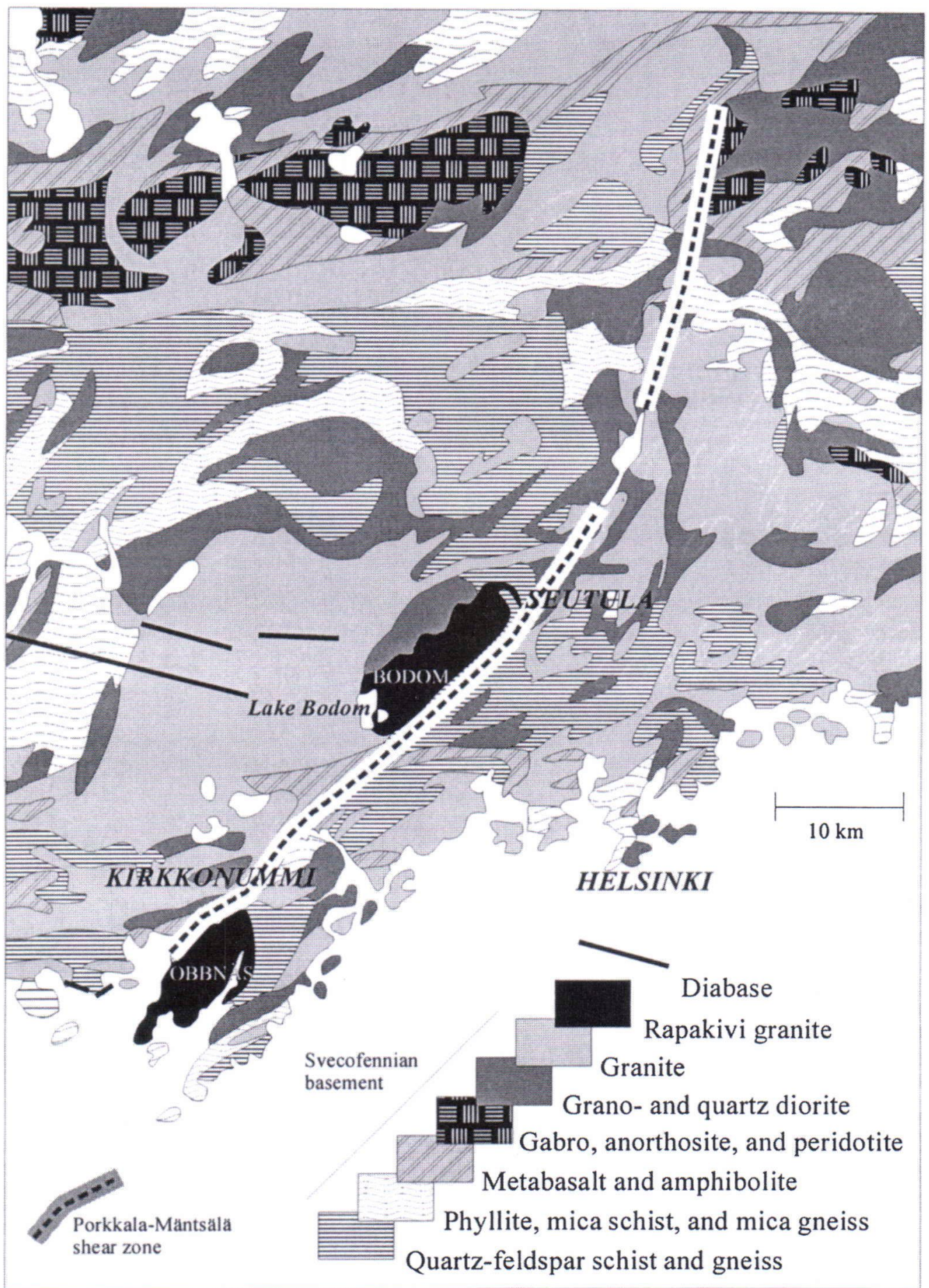

Fig. 1. a. Map showing the location and geological setting of the Bodom and Obbnäs plutons. After Laitakari et al. (1996) and Simonen (1980). Porkkala-Mäntsälä shear zone after Elminen (1999). b. Rapakivi granite plutons (dark grey) of the area surrounding the Gulf of Finland. After Koistinen (1994). 


\section{INTRODUCTION}

The Bodom and Obbnäs granite plutons intrude the Svecofennian bedrock west of Helsinki in southernmost Finland (Fig. 1). J. J. Sederholm described the plutons in some detail in 1926 and wrote: "The Bodom, as well as the Obbnäs granite, has in the most typical way penetrated the older rock masses, punching holes in them. There are no primary gradations between them and the older granitic formations. ... it seems indubitable that these granites are decidedly younger than the surrounding rocks" (Sederholm 1926, p. 101). Sederholm suggested that the Bodom and Obbnäs granites do not belong to the rapakivi granites of southeastern Finland, but that they are slightly older Late Precambrian granites. Halonen described the petrography of the Bodom pluton in his unpublished thesis in 1954, and the published data on these plutons consist of brief mentions, mostly in explanations to maps of rocks (Härme 1960, 1969, 1978, 1980; Laitala 1960, 1961, 1994; Vorma 1976).

Sederholm's suggestion that the Bodom and Obbnäs granites are older than the classic rapakivi granites of Finland was contradicted by the
U-Pb ages published by Vaasjoki (1977): the granites of both plutons were dated at $1645 \pm 5 \mathrm{Ma}$, which ties them, at least temporally, to the rapakivi granites of the Wiborg area. The question remained, however, whether the Bodom and Obbnäs granites are petrographically and chemically different from the rapakivi granites. In order to resolve this, the present author has remapped the two plutons in detail and conducted a geochemical and mineral chemical study on them. The purpose of this paper is to describe the lithologic and general geochemical traits of the plutons and make a comparison to the rapakivi granites of the Wiborg region. Petrochemistry and isotope geology of the Bodom and Obbnäs plutons will be discussed in detail in a parallel paper (Kosunen, Rämö \& Vaasjoki, in prep.).

\section{GEOLOGICAL SETTING}

The Bodom pluton is situated about $15 \mathrm{~km}$ northwest of Helsinki, extending from Lake Bodom in the southwest to the Seutula area in the northeast (Fig. 1). The pluton covers an area of about $60 \mathrm{~km}^{2}$ with a maximum length of $16.5 \mathrm{~km}$ and an aver-

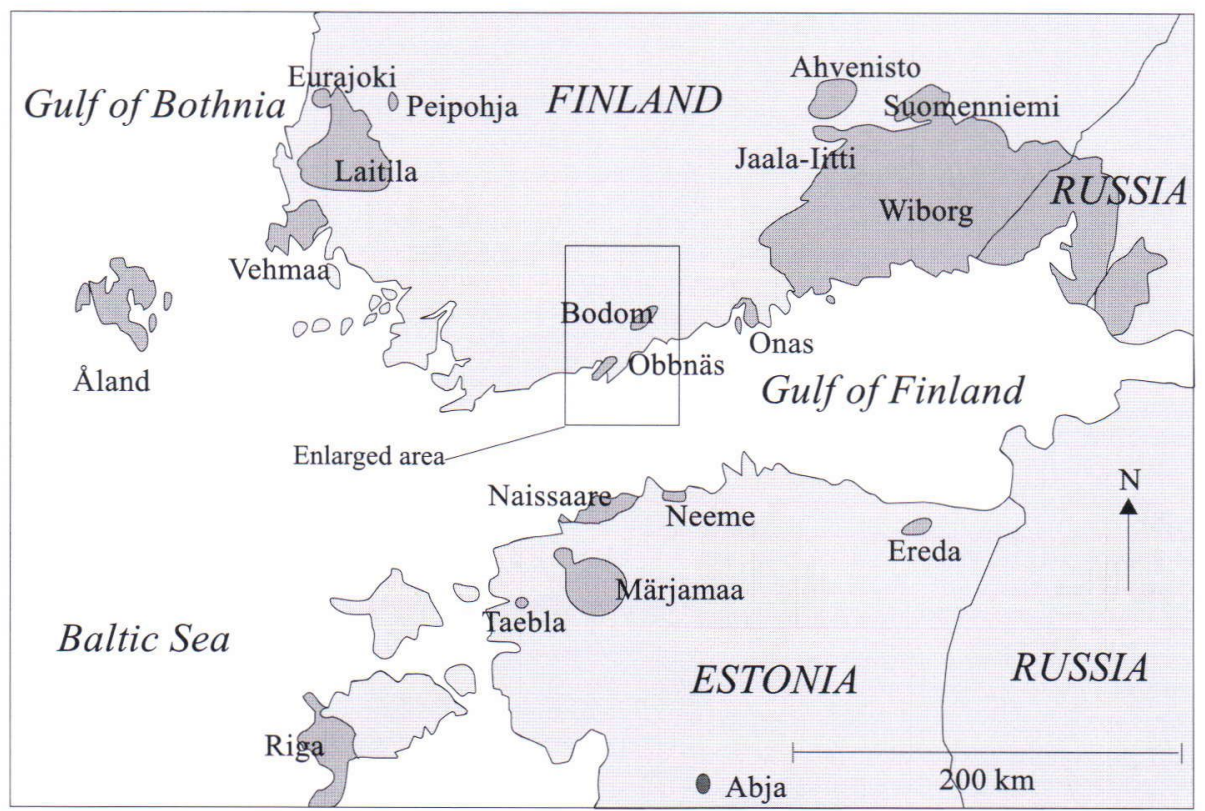


age width of $5 \mathrm{~km}$. The Obbnäs pluton is located about $20 \mathrm{~km}$ southwest of the Bodom pluton, south of Kirkkonummi, and encompasses an area of $50 \mathrm{~km}^{2}$, with a maximum length of 15 and width of $6 \mathrm{~km}$.

Both plutons cut sharply across the Paleoproterozoic metamorphic bedrock of southern Finland (Fig. 1). The country rocks adjacent to the Bodom and Obbnäs granites are Svecofennian quartz-feldspar schists and gneisses, mica gneisses, granodiorites and potassium granites, which range in age from 1900 to $1830 \mathrm{Ma}$ (Koistinen 1996). The granodiorites and potassium granites are generally migmatitic and typically heterogeneous, and therefore easily distinguishable from the quite homogeneous Bodom and Obbnäs granites. The intrusion of the plutons did not cause notable metamorphic changes in the country rocks as these had previously undergone relatively high-grade metamorphism.

Several NW-SE oriented diabase dikes, usually less than one meter wide, crosscut the Svecofennian supracrustal rocks and granitoids west of the Bodom and Obbnäs plutons (Aro \& Laitakari 1987). The dikes are clearly younger than the Svecofennian bedrock, and most likely belong to the rapakivi granite-associated Subjotnian diabases of southern Finland. A silicic-basic composite dike occurs on the island of Iso Haahkaluoto, in the immediate vicinity of the Obbnäs granite (Kosunen 1998).

The Bodom and Obbnäs plutons occur along the Porkkala-Mäntsälä shear zone (Fig. 1). The effects of movements along the zone are visible in both plutons; these include local deformation structures such as brittle shearing, en-echelon fractures, narrow bands of crushed quartz, and fractured feldspar megacrysts. Clear signs of deformation are always close to the shear zone. Some outcrops in the vicinity of the shear zone consist of entirely undeformed granite, so the shearing in the Porkkala-Mäntsälä zone must have been fairly local. It seems likely that the shear zone already existed before the intrusion of the granite magmas and acted as a pathway for them (Elminen 1999).

\section{FIELD RELATIONSHIPS AND PETROGRAPHY}

\section{Bodom}

Bodom granites (Fig. 2) are homogeneous and massive, and have a pronounced red or reddishbrown color, which makes it relatively easy to distinguish them from older Svecofennian granites and gneisses. The granites are also usually coarsergrained than the country rocks. Finer-grained varieties exist near the margin of the pluton with sporadic magmatic foliation, which is visible as parallel orientation of the alkali feldspar megacrysts. The external contacts of the pluton are typically sharp and cutting (Fig. 3b). Contact breccias with angular, well-preserved country rock fragments are locally found; fragments of variable size are especially abundant in the northeastern part of the pluton, in the area south of Seutula (Fig. 2).

The granites of the Bodom pluton can be divided into two main types, porphyritic and evengrained (see Halonen 1954). The porphyritic granite is here divided further into hornblende, biotitehornblende, and biotite granite on the basis of the mafic mineral assemblage; the areal extent of the different types is shown in Fig. 2. The porphyritic granites generally seem to grade into one another - only one locality with a sharp contact between hornblende-biotite granite and biotite granite has been found. The even-grained hornblende-biotite granite has a sharp contact against the porphyritic granite and is, most likely, a separate intrusion phase.

\section{Porphyritic granites}

The porphyritic granites of Bodom are red or reddish brown, medium- to coarse-grained rocks. They contain variable amounts of alkali feldspar megacrysts, which are chiefly euhedral or subhedral in the biotite and hornblende-biotite granites, and ovoidal in the hornblende granite (Figs. 3a, $3 \mathrm{~b}$, and $3 \mathrm{c}$ ). The size of the megacrysts varies from 1 by $2 \mathrm{~cm}$ to 4 by $4 \mathrm{~cm}$ and they are locally mantled by plagioclase. Drop quartz exists in the 


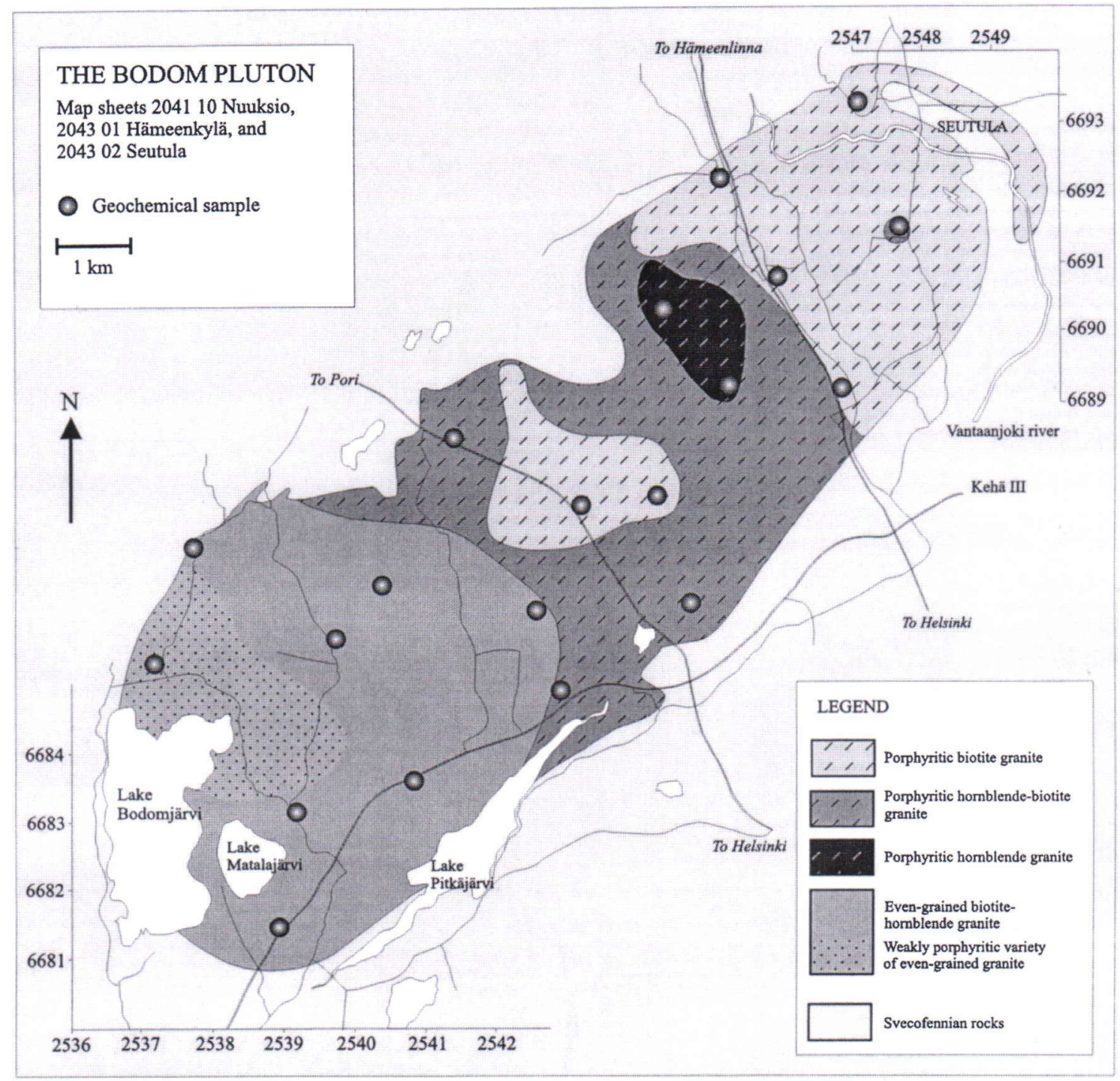

Fig. 2. Lithologic map of the Bodom pluton.

groundmass of all varieties but is most common in the hornblende granite in which the total amount of quartz is lowest.

The subhedral groundmass of the porphyritic granites is mainly composed of quartz, alkali feldspar, and plagioclase grains with diameters of 1 to $4 \mathrm{~mm}$. Alkali feldspar is perthitic microcline with a well-developed cross-hatch twinning. Plagioclase grains are zoned and the anorthite contents vary from $\mathrm{An}_{15-23}{ }^{1}$ in the biotite granite to $\mathrm{An}_{23-32}$ in the hornblende-biotite granite and $\mathrm{An}_{32-33}$ in the hornblende granite. The plagioclase grains of the hornblende granite frequently have albitic rims $\left(\mathrm{An}_{8-9}\right)$. The central parts of the plagioclase grains are commonly altered to sericite,

${ }^{1}$ The mineral compositions were determined from polished thin sections with a Cameca Camebax SX50 electron microprobe at the Geological Survey of Finland in Espoo. 

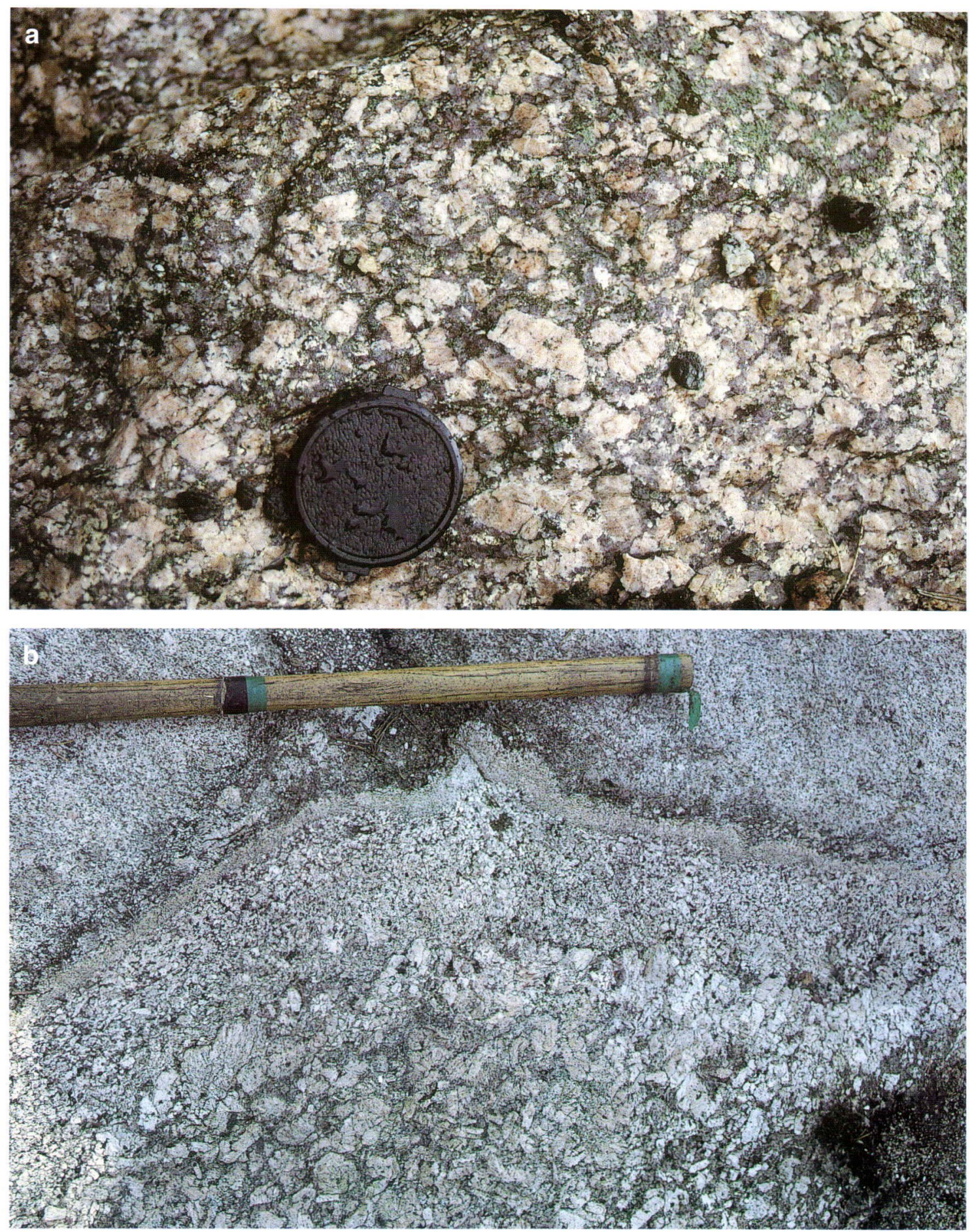

Fig. 3. Photographs of the different granite types of the Bodom pluton: a) porphyritic biotite granite, b) porphyritic hornblende-biotite granite with a chilled margin against country rock (Svecofennian gneissic granodiorite), c) porphyritic hornblende granite, d) even-grained hornblende-biotite granite. The diameter of the lens cover in 


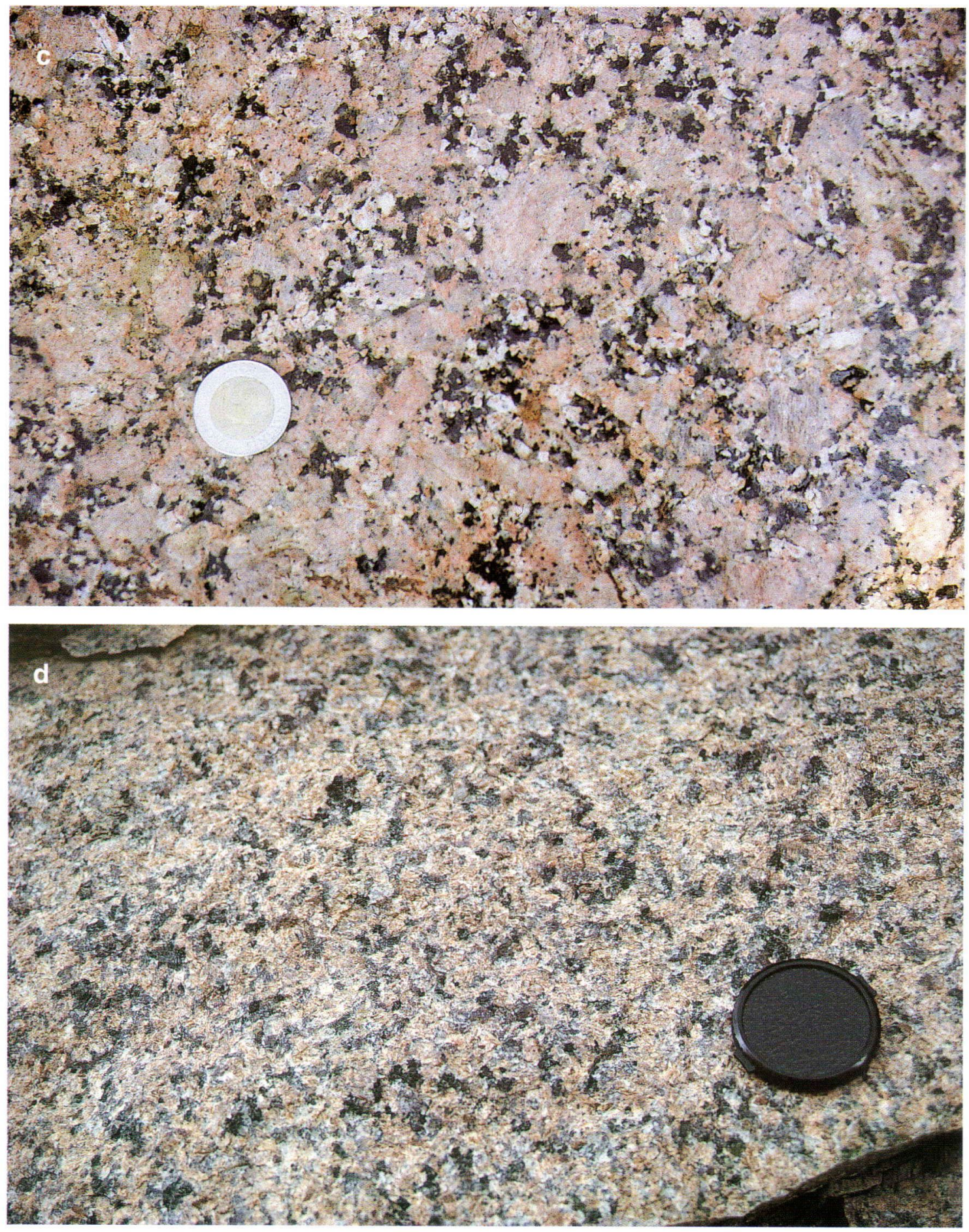

a) and d) is $5 \mathrm{~cm}$, the length of the hammer handle in b) is $45 \mathrm{~cm}$, and the diameter of the coin in c) is $2.7 \mathrm{~cm}$. Photos: P. Kosunen. 
in places also to muscovite and epidote. Biotite is the main mafic component of the biotite granite, although some grains contain remnants of amphibole and thus are probably secondary in origin. The hornblende-biotite granite is characterized by a slight preponderance of hastingsite over biotite, whereas the hornblende granite contains only a small amount of biotite produced by alteration of hastingsite or ferropargasite. The biotites are siderophyllitic, rather than annitic, when calculated to 22 oxygen atoms and $0 \mathrm{OH}$-groups. The margins of the biotite grains are commonly chloritized.

Fluorite, allanite, zircon, and apatite are accessory minerals in the porphyritic biotite granite; the hornblende-biotite granite has also oxides. The hornblende granite does not seem to contain any allanite and the amount of fluorite is lower than in the other two porphyritic varieties. The porphyritic hornblende granite contains a small amount of titanite, which occurs as sub- to euhedral grains, usually together with hornblende. Titanite is also found in the Obbnäs granites. It should be noted that titanite is a relatively common accessory mineral in some of the rapakivi-related granites of Estonia (Soesoo \& Niin 1992), the United States (Anderson 1980), and Brazil (Dall'Agnol et al. 1997), but is generally rare in the Finnish rapakivi granites (Laitakari et al. 1996).

\section{Even-grained hornblende-biotite granite}

The even-grained granite (Fig. 3d) is distinctly red, medium-grained, and more homogeneous in appearance than the porphyritic granites. The grain size typically varies from 2 to $5 \mathrm{~mm}$, but in the area north of Lake Bodomjärvi and Lake Matalajärvi (Fig. 2) the rock also contains euhedral alkali feldspar grains up to $5 \mathrm{~mm}$ wide by $10 \mathrm{~mm}$ long and has a weakly porphyritic texture.

The euhedral to anhedral alkali feldspar grains are crosshatched perthitic microcline, like in the porphyritic granites, and are locally rimmed by plagioclase or plagioclase and quartz. Both drop quartz and interstitial quartz is present. The composition of the plagioclase is $\mathrm{An}_{17-20}$ and the subhedral grains frequently have albitic rims $\left(\mathrm{An}_{1-2}\right)$.
The mafic minerals are iron-rich, siderophyllitic biotite and hastingsite or ferropargasite, which frequently form aggregates of several grains. Biotite is the sole mafic silicate in some places close to the outer margins of the even-grained granite. Alteration products include sericite, muscovite, epidote, and chlorite. Fluorite and allanite are the most common accessory minerals; zircon, apatite, and oxides occur less frequently.

\section{Obbnäs}

Lithological variation comparable to that in the Bodom pluton is not present in Obbnäs. The whole pluton is composed of porphyritic hornblende-biotite granite, except on the southernmost tip of the Obbnäs peninsula, Obbnäsudden, where three varieties of hybrid granitoids produced by magma mingling and mixing are exposed (Fig. 4). On the Obbnäs peninsula and Haukipää (Fig. 4) the porphyritic granite also contains mainly ovoidal magmatic microgranular enclaves. The pluton is clearly outlined with sharp, cutting contacts exposed especially in the southeast. A contact breccia is present in the northwestern rim of the pluton, where the granite encloses several angular fragments of older migmatitic granite. The porphyritic hornblende-biotite granite gradually becomes more mafic towards the southwestern part of the pluton where it seems to grade into the hybrid granitoids. Aplitic and pegmatitic dikes, 15 to $30 \mathrm{~cm}$ wide, are relatively common in the southern part of the pluton.

Magmatic foliation is frequently visible on the outcrops as parallel orientation of alkali feldspar megacrysts. More intense foliation and signs of brittle deformation are locally seen in the northwestern part of the pluton; they probably result from movements in the Porkkala-Mäntsälä shear zone during and after crystallization of the pluton.

\section{Porphyritic hornblende-biotite granite}

The porphyritic hornblende-biotite granite of Obbnäs (Fig. 5a) is coarser-grained than the porphyritic granites of Bodom, with groundmass grains varying mostly from 3 to $7 \mathrm{~mm}$ in diameter and 


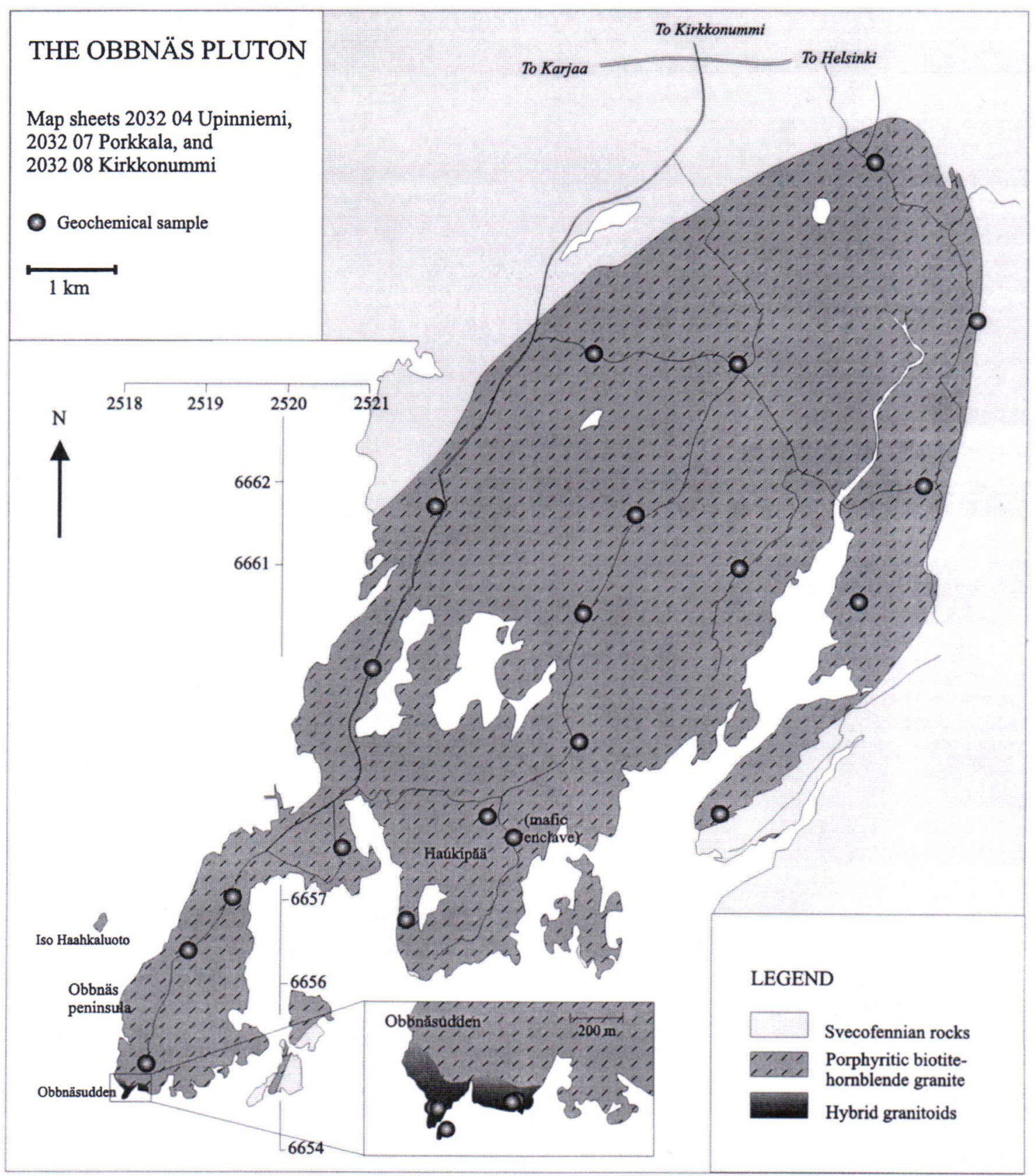

Fig. 4. Lithologic map of the Obbnäs pluton.

alkali feldspar megacrysts from 1 by $2 \mathrm{~cm}$ up to 5 by $5 \mathrm{~cm}$ in plan. The granite is red in the northern part of the pluton, and gets a reddish-brown hue towards the southwest, where it is more ma- fic in character. This change in character is accompanied by a change in texture: ovoidal megacrysts become more common, plagioclase mantles around megacrysts occur more frequently, and the 

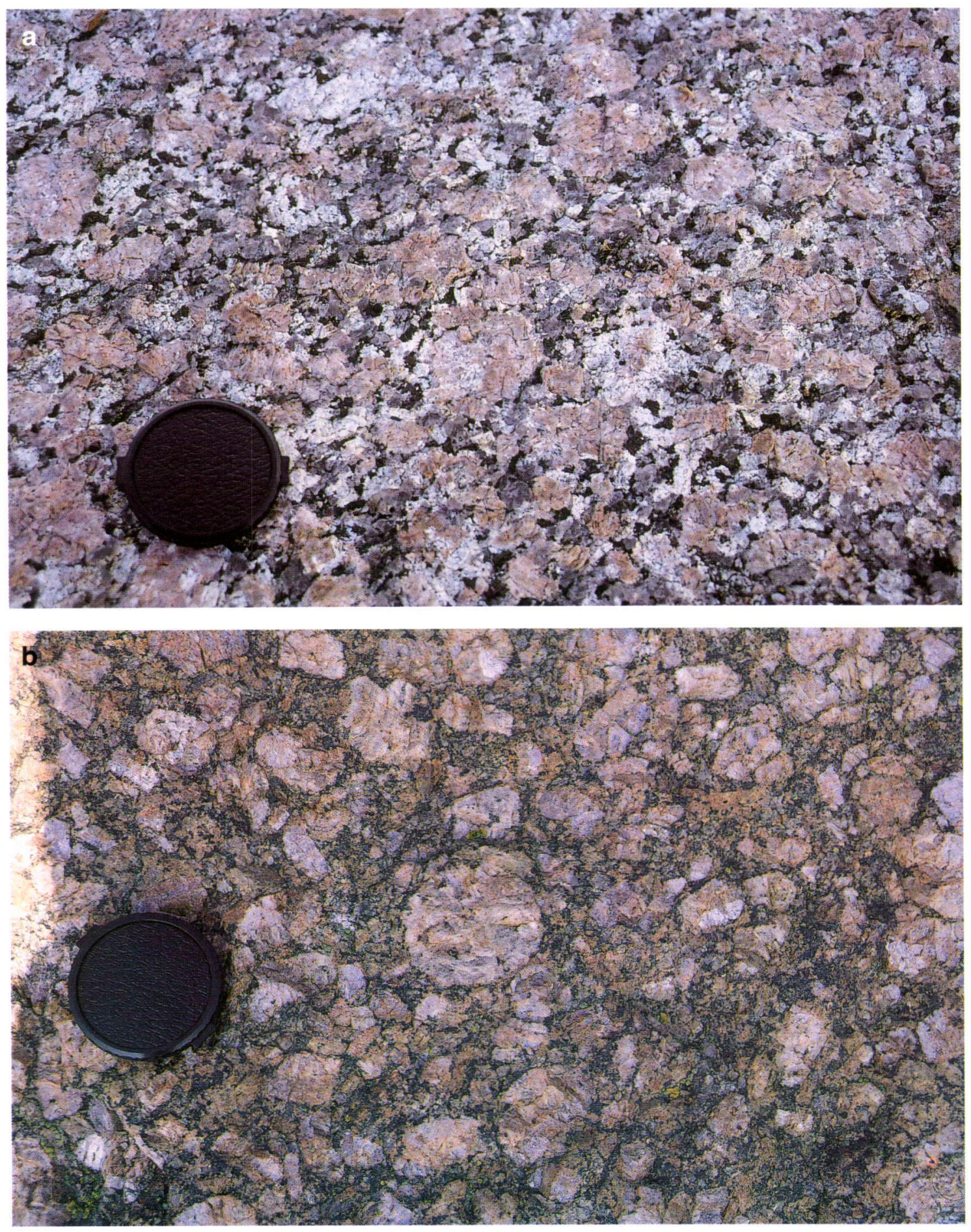

Fig. 5. Photographs of the porphyritic hornblende-biotite granite of Obbnäs: a) typical granite in the northern part of the pluton, $b$ ) the slightly more mafic granite variety in the southern part of the pluton. The diameter of the lens cover is $5 \mathrm{~cm}$. Photos by P. Kosunen. 
groundmass gets less coarse (Fig. 5b). In the southern part of the pluton some euhedral plagioclase grains are present, these are coarser than the groundmass and vary in plan from 0.5 by $1 \mathrm{~cm}$ to 1 by $2 \mathrm{~cm}$.

The alkali feldspar of both the groundmass and the megacrysts is crosshatched microcline. The megacrysts typically contain relatively coarse perthite lamellae as well as small euhedral crystals of plagioclase and quartz. In addition to alkali feldspar, the groundmass contains variable amounts of quartz, plagioclase $\left(\mathrm{An}_{23-27}\right)$, siderophyllitic biotite, and hastingsite. The plagioclase grains are commonly altered to sericite, and muscovite, epidote and carbonate also occur in places. Biotite grains occasionally have chloritized rims. Accessory euhedral or subhedral titanite, metamict allanite, and interstitial fluorite are generally encountered with the main mafic constituents. Small euhedral zircon, apatite, and oxide grains are also present.

Signs of brittle deformation are frequently visible in thin section: quartz grains display ubiquitous undulose extinction, biotite grains and plagioclase twin-lamellae are locally bent, and deformation lamellae can be seen in titanite grains. In the northwestern part of the pluton, where deformation has been most intense, quartz is sheared and fine-grained, and alkali feldspar megacrysts are broken with fractures often filled with quartz, chlorite, and epidote.

\section{Evidence of interaction of two magmas: hybrid granitoids and magmatic microgranular enclaves}

The well-exposed seashore outcrops of Obbnäsudden, the southernmost tip of the Obbnäs peninsula (Fig. 4), comprise several Svecofennian rock types and three types of hybrid granitoids, which belong to the Obbnäs pluton. The latter are, most likely, results of mingling and mixing of two magmas of slightly different composition. One of the hybrid granitoids is even-grained; the other two types are porphyritic and differ from each other by the amount of alkali feldspar megacrysts they contain. The type that contains abundant alkali feldspar megacrysts is here called 'densely porphyritic' (Fig. 6a), whereas the type that has only few megacrysts is 'sparsely porphyritic' (Fig. 6b). The composition of the hybrid granitoids varies from granitic (densely porphyritic) to granodioritic (sparsely porphyritic and even-grained). The even-grained granitoid is found on a small islet just south of Obbnäsudden, in contact with the densely porphyritic granitoid (Fig. 6c). The sparsely porphyritic type generally occurs as irregular areas within the densely porphyritic granitoid, which probably grades into the porphyritic hornblende-biotite granite of Obbnäs. The contacts between the two porphyritic types are everywhere well defined, but not cutting, and in places it is possible to see alkali feldspar megacrysts on their way from the densely porphyritic granitoid into the sparsely porphyritic granitoid (Fig. 6d). The sparsely porphyritic granitoid is interpreted as the result of intrusion of more mafic material into the alkali feldspar megacryst-bearing densely porphyritic granite melt, which had already been hybridized in a preceding mixing event. The older Svecofennian granite and gneisses present on Obbnäsudden are clearly cut by the hybrid granitoids, and locally occur as fragments in them (Fig. 6e).

In addition to the ovoidal alkali feldspar megacrysts ( 2 to $5 \mathrm{~cm}$ in diameter), the porphyritic hybrid granitoids contain euhedral grains of plagioclase, which are clearly coarser $(0.5$ by $1 \mathrm{~cm}$ to 1 by $2 \mathrm{~cm}$ in plan) than the groundmass. The sparsely porphyritic granite also contains some relatively large quartz grains (diameter up to $1 \mathrm{~cm}$ ), as well as mineral aggregates coarser than the groundmass in general. The megacrysts of the sparsely porphyritic granite - alkali feldspar, plagioclase, and quartz - are commonly rounded and have a slightly corroded appearance, which is one of the features indicative of mingling of mafic and felsic components in a bimodal magmatic association (e.g. Cantagrel et al. 1984, Didier 1987, Salonsaari \& Haapala 1994, Salonsaari 1995). Among the other features typical of the hybrid rocks, needle-like apatite is found in the granitoids of Obbnäsudden, but corona textures (amphibole rims around quartz grains and micrographic pla- 

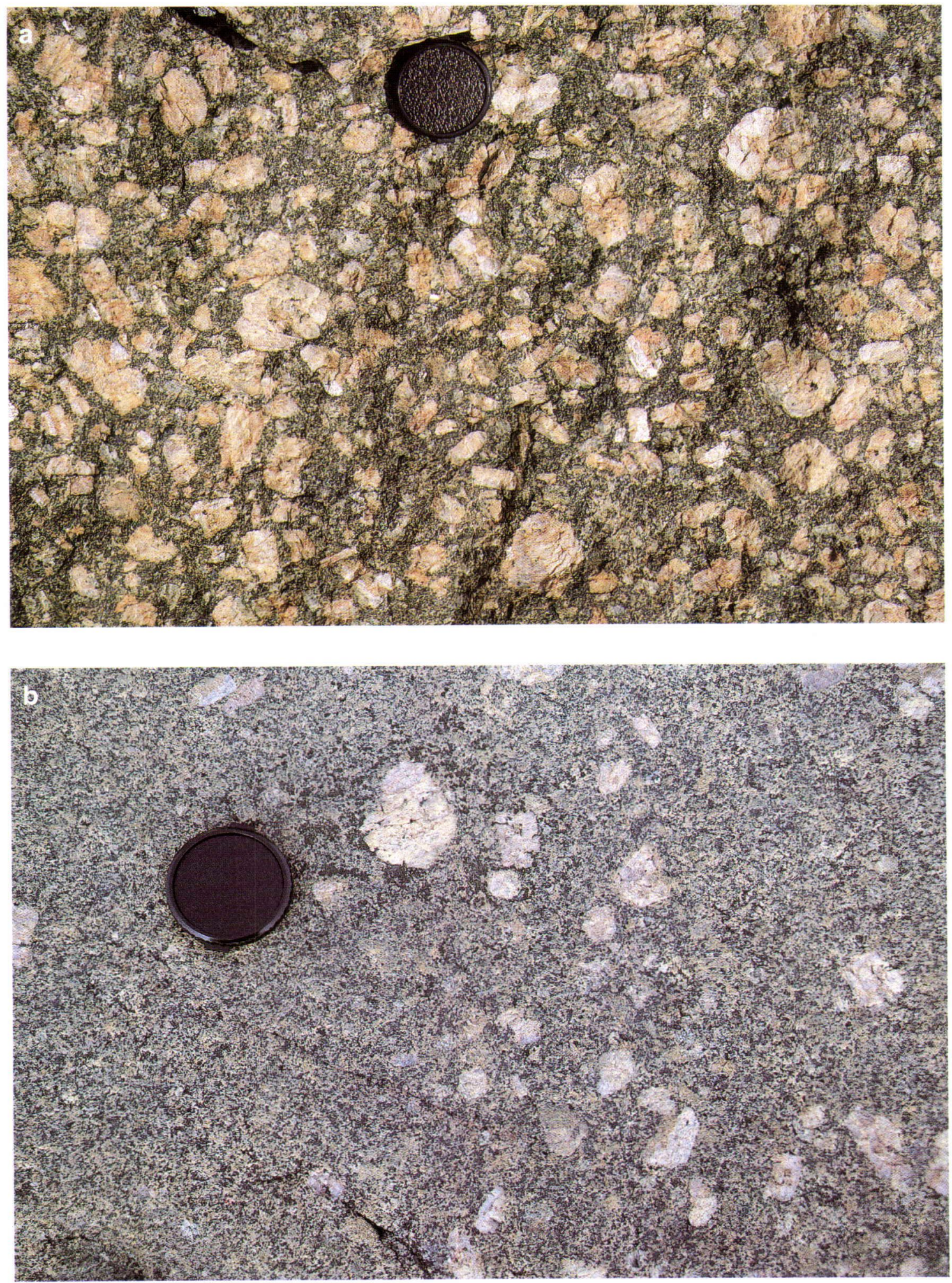
Fig. 6. Photographs of the hybrid granitoids in the southern part of the Obbnäs pluton: a) densely porphyritic hybrid granitoid, b) sparsely porphyritic hybrid granitoid, c) even-grained hybrid granitoid in contact with the densely porphyritic hybrid granitoid, $d$ ) alkali feldspar megacrysts on their way from the densely porphyritic hybrid granitoid into the sparsely porphyritic hybrid granitoid, e) country rock fragments in the densely porphyritic hybrid granitoid on the southernmost tip of Obbnäsudden, f) a mafic magmatic enclave in the porphyritic hornblende-biotite granite. The diameter of the lens cover in a) and b) is $5 \mathrm{~cm}$, the length of the hammer in c) is $65 \mathrm{~cm}$, the size of the compass in d) and e) is 6.5 by $12.5 \mathrm{~cm}$, and the length of the pen in f) is 15 $\mathrm{cm}$. Photos by P. Kosunen, except c) by O. Tapani Rämö.
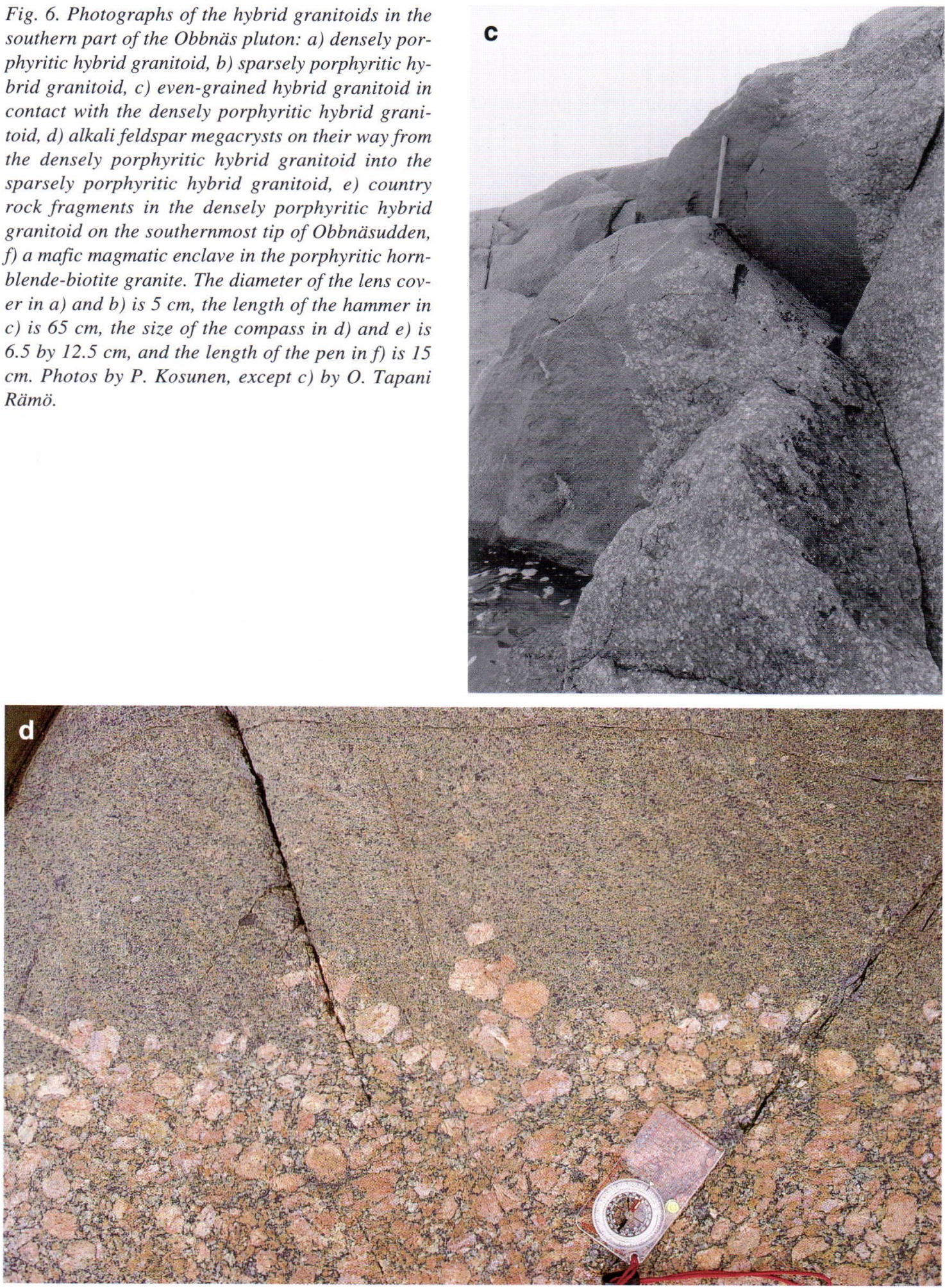


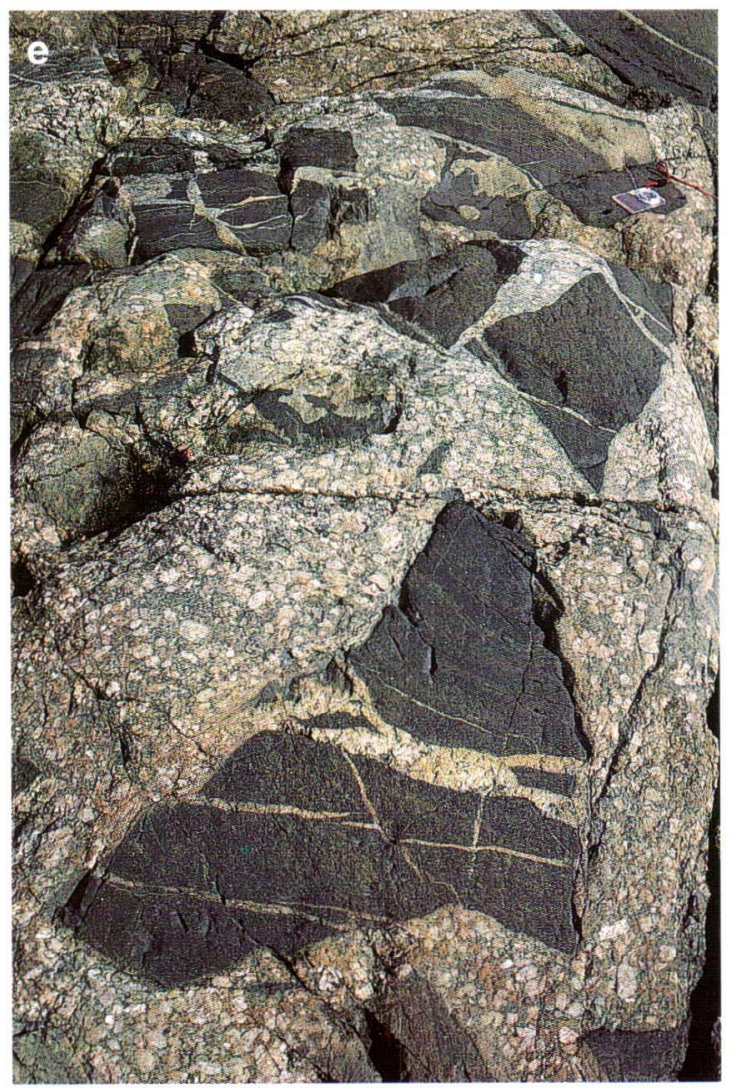

gioclase-quartz mantles surrounding alkali feldspar grains) are not present.

The groundmass of the densely porphyritic hybrid granitoid contains the same mineral assemblage as the porphyritic hornblende-biotite granite, but the amounts of plagioclase, amphibole, biotite, titanite, and oxides are higher, and the amounts of alkali feldspar, quartz, allanite, zircon, and fluorite lower. The groundmass of the sparsely porphyritic granitoid is finer-grained ( 0.5 to $1 \mathrm{~mm}$ ) than that of the densely porphyritic type (1 to 3 $\mathrm{mm}$ ), and contains abundant amphibole, biotite, titanite, and oxides. Plagioclase clearly predominates over alkali feldspar, quartz is less common than in the densely porphyritic type, zircon and allanite are rare, and fluorite is missing. The evengrained hybrid granitoid is similar to the sparsely porphyritic one, but does not contain any alkali feldspar megacrysts. All the hybrid granitoids also

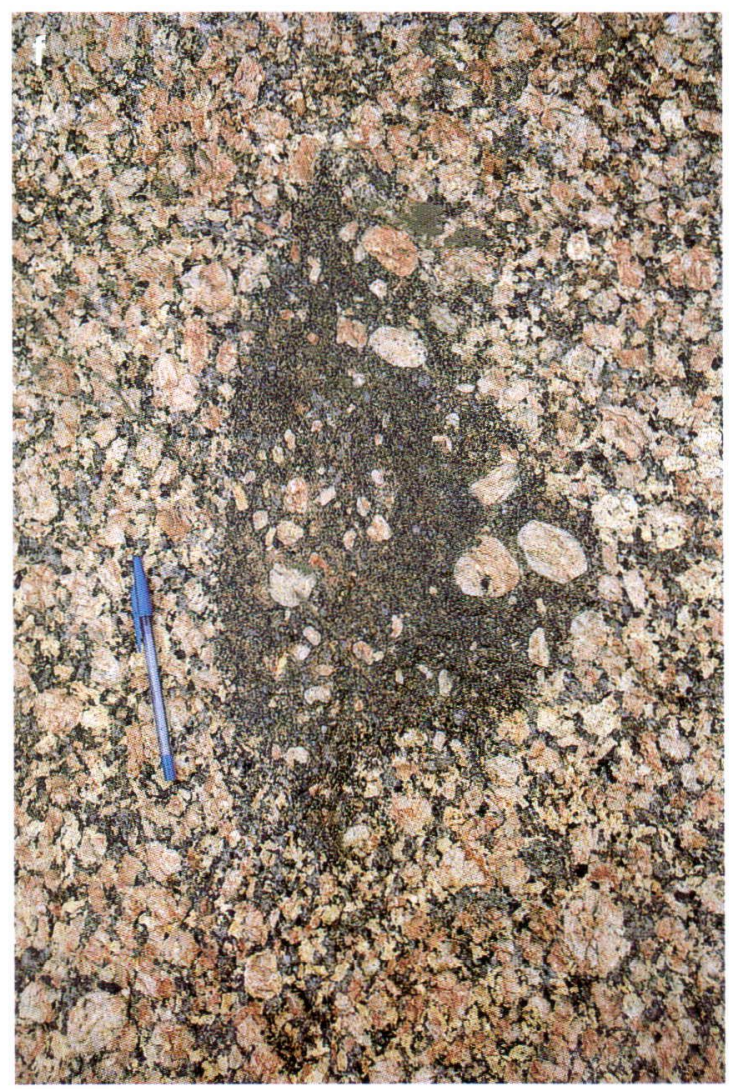

contain accessory apatite that is occasionally found as needle-like crystals. The An-content of plagioclase is $28-37 \%$ in the densely porphyritic granitoid and 36-41\% in the sparsely porphyritic granite; biotite of both types is siderophyllitic ( $22 \mathrm{O}$, anhydrous), and amphibole is ferropargasite or hastingsite. Compositions of the minerals in the even-grained variety have not been determined.

Relatively mafic microgranular enclaves of magmatic origin can be found in several places in the porphyritic hornblende-biotite granite of the southern Obbnäs pluton, especially in the area of Haukipää and Obbnäs peninsula (Fig. 4). The enclaves are usually ovoidal - deformed elongated enclaves are found in places - and vary in size from 10 to $50 \mathrm{~cm}$ (Fig. 6f). They are finer-grained than the surrounding granite, contain variable amounts of alkali feldspar megacrysts, and commonly bear a resemblance to the sparsely porphy- 
ritic hybrid granitoid of Obbnäsudden. Some enclaves contain megacrysts that are partially inside the surrounding granite, suggesting that the megacrysts originally crystallized from the granitic magma and were subsequently engulfed by globules of more mafic magma intruding into the crystallizing magma chamber.

\section{WHOLE-ROCK GEOCHEMISTRY}

\section{Samples and analytical methods}

Twenty samples were analyzed for major and trace element compositions of the Bodom pluton: six samples from the porphyritic biotite granite, four from the porphyritic hornblende-biotite granite, two from the porphyritic hornblende granite, and eight from the even-grained granite. Twenty-five samples came from the Obbnäs pluton: 19 from the porphyritic hornblende-biotite granite, five from the hybrid granitoids of Obbnäsudden (one from the even-grained type and two from both porphyritic types), and one from a magmatic microgranular enclave in the porphyritic hornblendebiotite granite. Most of the samples were taken by Dr. Seppo Lahti of the Geological Survey of Finland in 1984; one sample from the porphyritic hornblende granite of Bodom, one from the porphyritic hornblende-biotite granite of Obbnäs, and the samples from the hybrid granitoids and the microgranular enclave were taken by the author in 1996 and 1998. Sample locations are shown in Figs. 2 and 4.

The samples were crushed with a manganesesteel jaw crusher and milled in a carbon-steel pan. Most of the samples were analyzed at the Geological Survey of Finland in Otaniemi, Espoo. Five samples were analyzed at the XRAL Laboratories in Ontario, Canada; these include one sample from each of the porphyritic hybrid granitoids, the sample from the even-grained granitoid and the magmatic microgranular enclave, and a sample from the porphyritic hornblende granite of Bodom. The major elements (Na, Mg, Al, Si, P, K, Ca, Ti, Mn, and $\mathrm{Fe}$ ) as well as some of the trace elements ( $\mathrm{S}$, $\mathrm{Cl}, \mathrm{V}, \mathrm{Cu}, \mathrm{Zn}, \mathrm{Rb}, \mathrm{Sr}, \mathrm{Ba}$, and $\mathrm{Pb}$ ) were analyzed by XRF, rare earth elements and trace elements Y, Sc, Th, U, Hf, Nb, Ta, Ga, and Zr by ICP-MS. Loss on ignition (L.O.I) was determined gravimetrically at $1000{ }^{\circ} \mathrm{C}$ and fluorine by ion-specific electrode.

\section{Major elements}

The major element compositions of the Bodom and Obbnäs granites and the hybrid granitoids are given in Table 1 and shown in Figs. 7 through 9. For comparison, the composition of Finnish rapakivi granites is shown as fields in the diagrams.

According to the classification of plutonic igneous rocks that is based upon cation proportions (De la Roche et al. 1980), the Bodom granites are syenogranites while the samples from the Obbnäs granite fall in the fields of syeno- and monzogranites (Fig. 7). The densely porphyritic hybrid granitoid also has a granitic composition and the sparsely porphyritic and the even-grained types are granodioritic. The average major element compositions of the Bodom and Obbnäs granites and the porphyritic hybrid granitoids are shown in Table 1; the complete set of analytical data is available from the author by request.

The porphyritic hornblende granite of Bodom contains 64.9 to $69.7 \mathrm{wt} \% \mathrm{SiO}_{2}$, porphyritic hornblende-biotite granite 69.7 to $73.7 \mathrm{wt} \% \mathrm{SiO}_{2}$, porphyritic biotite granite 71.4 to $75.4 \mathrm{wt} \% \mathrm{SiO}_{2}$, and even-grained granite 69.6 to $74.0 \mathrm{wt} \% \mathrm{SiO}_{2}$ (Fig. $8)$. The major element compositions of the porphyritic granites overlap, but a trend of increasing silica content is obvious in the average compositions: the hornblende granite has $67.3 \mathrm{wt} \%$ $\mathrm{SiO}_{2}$, the hornblende-biotite granite $71.4 \mathrm{wt} \%$ $\mathrm{SiO}_{2}$, and the biotite granite $73.3 \mathrm{wt} \% \mathrm{SiO}_{2}(\mathrm{Ta}-$ ble 1). Also, the average amount of $\mathrm{FeO}_{\text {tot }}, \mathrm{TiO}_{2}$, $\mathrm{Al}_{2} \mathrm{O}_{3}, \mathrm{MgO}$, and $\mathrm{P}_{2} \mathrm{O}_{5}$ decreases from hornblende granite to biotite granite. The even-grained granite has an average major element composition close to that of the porphyritic biotite granite but is more homogeneous. Two samples of evengrained granite have a lower content of $\mathrm{SiO}_{2}$, and a higher content of $\mathrm{Al}_{2} \mathrm{O}_{3}, \mathrm{MnO}, \mathrm{FeO}_{\text {tot }}$, and $\mathrm{K}_{2} \mathrm{O}$ than average (Fig. 8).

The porphyritic hornblende-biotite granite of 
Table 1. Average major element compositions of the Bodom and Obbnäs granites and the porphyritic hybrid granitoids*

\begin{tabular}{|c|c|c|c|c|}
\hline \multirow[b]{3}{*}{$\mathrm{wt} \%$} & \multicolumn{4}{|c|}{ BODOM } \\
\hline & \multicolumn{3}{|c|}{ Porphyritic granites } & \multirow{2}{*}{$\begin{array}{l}\text { Even-grainec } \\
\text { granite } \\
(\mathrm{n}=8)\end{array}$} \\
\hline & $\begin{array}{l}\text { Hbl-granite } \\
\quad(\mathrm{n}=2)\end{array}$ & $\begin{array}{l}\text { Hbl-bt-granite } \\
\quad(\mathrm{n}=4)\end{array}$ & $\begin{array}{l}\text { Bt-granite } \\
\quad(n=6)\end{array}$ & \\
\hline $\mathrm{SiO}_{2}$ & $67.30 \pm 3.39$ & $71.35 \pm 1.69$ & $73.30 \pm 1.43$ & $72.38 \pm 1.72$ \\
\hline $\mathrm{TiO}_{2}$ & $0.41 \pm 0.21$ & $0.24 \pm 0.02$ & $0.16 \pm 0.02$ & $0.22 \pm 0.04$ \\
\hline $\mathrm{Al}_{2} \mathrm{O}_{3}$ & $14.05 \pm 0.21$ & $13.38 \pm 0.67$ & $12.72 \pm 0.73$ & $12.39 \pm 0.54$ \\
\hline $\mathrm{FeO}_{\text {tot }}$ & $5.27 \pm 2.51$ & $3.23 \pm 0.22$ & $2.48 \pm 0.44$ & $3.48 \pm 0.54$ \\
\hline $\mathrm{Fe}_{2} \mathrm{O}_{3 \text { tot }}$ & $5.85 \pm 2.79$ & $3.59 \pm 0.24$ & $2.75 \pm 0.49$ & $3.87 \pm 0.60$ \\
\hline $\mathrm{MnO}$ & $0.08 \pm 0.05$ & $0.04 \pm 0.01$ & $0.03 \pm 0.01$ & $0.04 \pm 0.01$ \\
\hline $\mathrm{MgO}$ & $0.31 \pm 0.01$ & $0.19 \pm 0.05$ & $0.18 \pm 0.11$ & $0.16 \pm 0.07$ \\
\hline $\mathrm{CaO}$ & $2.09 \pm 1.41$ & $1.19 \pm 0.12$ & $1.06 \pm 0.16$ & $1.24 \pm 0.12$ \\
\hline $\mathrm{Na}_{2} \mathrm{O}$ & $2.95 \pm 0.24$ & $2.70 \pm 0.13$ & $2.67 \pm 0.19$ & $2.50 \pm 0.14$ \\
\hline $\mathrm{K}_{2} \mathrm{O}$ & $5.68 \pm 1.48$ & $6.01 \pm 0.59$ & $5.63 \pm 0.62$ & $5.83 \pm 0.23$ \\
\hline $\mathrm{P}_{2} \mathrm{O}_{5}$ & $0.062 \pm 0.040$ & $0.033 \pm 0.005$ & $0.024 \pm 0.007$ & - \\
\hline LOI & $0.48 \pm 0.18$ & $0.45 \pm 0.13$ & $0.75 \pm 0.15$ & $0.76 \pm 0.20$ \\
\hline Total & $98.97 \pm 0.69$ & $99.06 \pm 0.43$ & $99.37 \pm 0.31$ & $99.57 \pm 0.50$ \\
\hline ACNK & $0.96 \pm 0.11$ & $1.02 \pm 0.01$ & $1.03 \pm 0.04$ & $0.98 \pm 0.01$ \\
\hline $\mathrm{K}_{2} \mathrm{O} / \mathrm{Na}_{2} \mathrm{O}$ & $1.95 \pm 0.66$ & $2.23 \pm 0.23$ & $2.13 \pm 0.35$ & $2.34 \pm 0.11$ \\
\hline $\mathrm{Fe} / \mathrm{Mg}$ & $0.94 \pm 0.03$ & $0.94 \pm 0.01$ & $0.93 \pm 0.04$ & $0.95 \pm 0.02$ \\
\hline
\end{tabular}

\section{OBBNÄS}

\begin{tabular}{ccc}
\hline $\begin{array}{c}\text { Porphyritic hbl- } \\
\text { bt-granite }\end{array}$ & $\begin{array}{c}\text { Densely porphyr. } \\
\text { hybrid granitoid }\end{array}$ & $\begin{array}{c}\text { Sparsely porphyr. } \\
\text { hybrid granitoid }\end{array}$
\end{tabular}

\begin{tabular}{lcrr}
$\mathrm{wt} \%$ & \multicolumn{1}{c}{$(\mathrm{n}=19)$} & \multicolumn{1}{c}{$(\mathrm{n}=2)$} & \multicolumn{1}{c}{$(\mathrm{n}=2)$} \\
\hline $\mathrm{SiO}_{2}$ & $70.14 \pm 2.10$ & $66.05 \pm 0.64$ & $62.60 \pm 0.28$ \\
$\mathrm{TiO}_{2}$ & $0.38 \pm 0.14$ & $0.53 \pm 0.08$ & $1.18 \pm 0.07$ \\
$\mathrm{Al}_{2} \mathrm{O}_{3}$ & $13.99 \pm 0.79$ & $15.20 \pm 0.42$ & $14.25 \pm 0.35$ \\
$\mathrm{FeO}_{\text {tot }}$ & $3.42 \pm 0.90$ & $4.26 \pm 0.75$ & $8.02 \pm 0.16$ \\
$\mathrm{Fe}_{2} \mathrm{O}_{3 \text { tot }}$ & $3.80 \pm 1.00$ & $4.73 \pm 0.83$ & $8.91 \pm 0.17$ \\
$\mathrm{MnO}$ & $0.04 \pm 0.01$ & $0.05 \pm 0.02$ & $0.11 \pm 0.00$ \\
$\mathrm{MgO}$ & $0.53 \pm 0.22$ & $0.68 \pm 0.00$ & $1.29 \pm 0.31$ \\
$\mathrm{CaO}$ & $1.46 \pm 0.48$ & $2.16 \pm 0.50$ & $4.08 \pm 0.25$ \\
$\mathrm{Na} 2 \mathrm{O}$ & $2.78 \pm 0.32$ & $2.71 \pm 0.12$ & $2.71 \pm 0.17$ \\
$\mathrm{~K}_{2} \mathrm{O}$ & $5.64 \pm 0.59$ & $6.05 \pm 0.92$ & $3.51 \pm 0.37$ \\
$\mathrm{P}_{2} \mathrm{O}_{5}$ & $0.096 \pm 0.044$ & $0.166 \pm 0.023$ & $0.421 \pm 0.013$ \\
$\mathrm{LOI}$ & $0.68 \pm 0.29$ & $0.70 \pm 0.14$ & $0.63 \pm 0.11$ \\
\hline $\mathrm{Total}$ & $99.35 \pm 0.35$ & $98.76 \pm 1.02$ & $99.15 \pm 0.42$ \\
$\mathrm{ACNK}$ & $1.05 \pm 0.04$ & $1.02 \pm 0.04$ & $0.91 \pm 0.04$ \\
$\mathrm{~K}_{2} \mathrm{O} / \mathrm{Na}_{2} \mathrm{O}$ & $2.06 \pm 0.36$ & $2.25 \pm 0.44$ & $1.29 \pm 0.06$ \\
$\mathrm{Fe} / \mathrm{Mg}$ & $0.87 \pm 0.04$ & $0.86 \pm 0.02$ & $0.86 \pm 0.03$ \\
\hline
\end{tabular}

* The analytical data is available from the author by request.

$\mathrm{FeO}_{\text {tot }}$ calculated from $\mathrm{Fe}_{2} \mathrm{O}_{3 \text { tot }}$ according to Ragland (1989)

$\mathrm{ACNK}=\mathrm{Al}_{2} \mathrm{O}_{3} /\left(\mathrm{Na}_{2} \mathrm{O}+\mathrm{CaO}+\mathrm{K}_{2} \mathrm{O}\right)$, molar ratio

$\mathrm{Fe} / \mathrm{Mg}=\mathrm{FeO}_{\text {tot }} /\left(\mathrm{FeO}_{\text {tot }}+\mathrm{MgO}\right)$ 


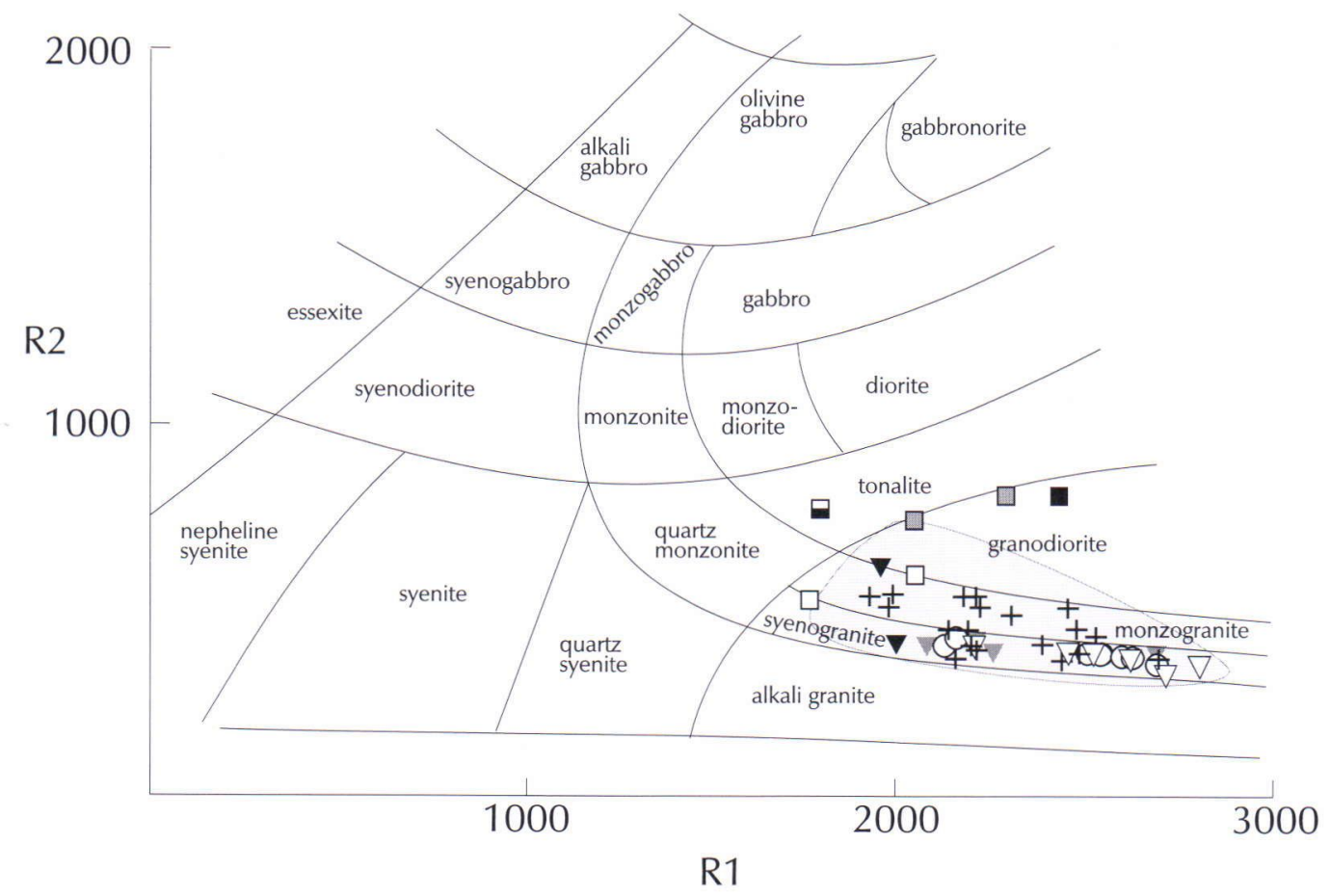

Finnish rapakivi granites

Obbnäs

\section{Bodom}

v Porphyritic hornblende granite

จ Porphyritic hornblende-biotite granite

$\nabla$ Porphyritic biotite granite

$\bigcirc$ Even-grained granite
- Even-grained hybrid granitoid

$\square$ Sparsely porphyritic hybrid granitoid

$\square$ Densely porphyritic hybrid granitoid

- Magmatic microgranular enclave in porphyritic hornblende-biotite granite

+ Porphyritic hornblende-biotite granite

Fig. 7. Classification of the Bodom and Obbnäs granites and the hybrid granitoids using the parameters R1 and $R 2$ (De la Roche et al. 1980), calculated from millication proportions. $R 1=4 \mathrm{Si}-11(\mathrm{Na}+\mathrm{K})-2(\mathrm{Fe}+\mathrm{Ti}) ; \mathrm{R} 2$ $=6 \mathrm{Ca}+2 \mathrm{Mg}+\mathrm{Al}$. The data that were used to construct the fields for the Finnish rapakivi granites include rocks from the rapakivi areas of Wiborg (Sahama 1945, Lokka 1950, Rieder et al. 1996), Suomenniemi (Rämö 1991), Jaala-Iitti (Salonsaari 1995), Ahvenisto (Savolahti 1956), Laitila (Sahama 1945, Lokka 1950, Vorma 1976), Vehmaa (Sahama 1945), Eurajoki (Haapala 1977), and Åland (Sahama 1945).

Obbnäs is less evolved in character than the Bodom granites. It contains 66.4 to $73.8 \mathrm{wt} \% \mathrm{SiO}_{2}$ and has a generally lower content of $\mathrm{K}_{2} \mathrm{O}$, and a higher content of $\mathrm{TiO}_{2}, \mathrm{CaO}, \mathrm{MgO}$, and $\mathrm{P}_{2} \mathrm{O}_{5}$ than the latter (Fig. 8 and Table 1). Samples with the least evolved major element composition are present in the southern part of the pluton, in agreement with the field observations of the more mafic nature of the granite in the southwest. The densely porphyritic hybrid granitoid contains 65.6 to $66.5 \mathrm{wt} \% \mathrm{SiO}_{2}$, and has a major element composition similar to that of the least evolved samples of the porphyritic hornblende-biotite granite (Fig. 8). The compositions of the sparsely porphyritic and even-grained granitoids are more primitive with 62.4 to 62.8 and $64.6 \mathrm{wt} \% \mathrm{SiO}_{2}$, respectively, which is probably due to a smaller proportion of alkali feldspar megacrysts in the mixture. 

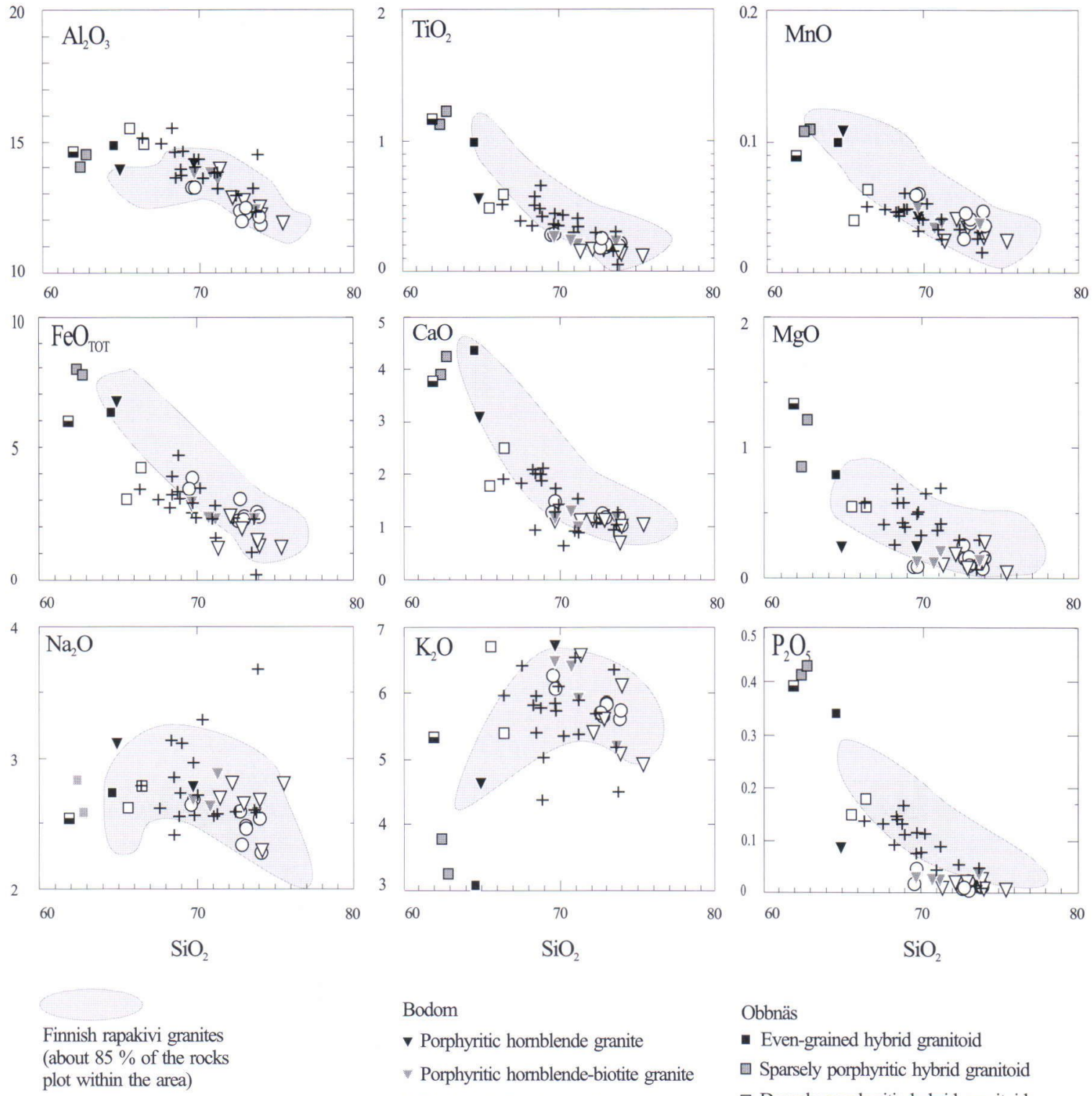

Bodom

- Porphyritic hornblende granite

* Porphyritic homblende-biotite granite

$\nabla$ Porphyritic biotite granite

o Even-grained granite
Obbnäs

- Even-grained hybrid granitoid

$\square$ Sparsely porphyritic hybrid granitoid

$\square$ Densely porphyritic hybrid granitoid

ఐ Magmatic microgranular enclave in porphyritic homblende-biotite granite

+ Porphyritic hornblende-biotite granite

Fig. 8. Harker-variation diagrams for the major element compositions (wt\%) of the Bodom and Obbnäs granites and the hybrid granitoids. Data for the Finnish rapakivi granite fields as in Fig. 7.

The magmatic microgranular enclave contains $61.9 \mathrm{wt} \% \mathrm{SiO}_{2}$ and resembles the sparsely porphyritic granitoid.

About $85 \%$ of the Finnish rapakivi granites plot within the gray fields in Fig. 8, as do most of the Bodom and Obbnäs granites. The most notable differences between the major element compositions of the Bodom and Obbnäs granites and the 
other Finnish rapakivi granites seem to be the lower $\mathrm{P}_{2} \mathrm{O}_{5}$ in Bodom and lower $\mathrm{FeO}_{\text {tot }}$ and partly higher $\mathrm{Al}_{2} \mathrm{O}_{3}$ in Obbnäs.

According to Fig. 9, both the Bodom and Obbnäs granites are subalkaline, peraluminous to metaluminous granites, with average $\mathrm{A} / \mathrm{CNK}$ values of 1.00 and 1.05, and $\mathrm{K}_{2} \mathrm{O} / \mathrm{Na}_{2} \mathrm{O}$ of 2.22 and 2.06, respectively; the corresponding average values for Finnish rapakivi granites are 0.99 and 2.33 (Rämö \& Haapala 1995). The granites of both plutons also have the high $\mathrm{Fe} / \mathrm{Mg}$ typical of rapakivi granites: the average $\mathrm{FeO}_{\text {tot }} /\left(\mathrm{FeO}_{\text {tot }}+\mathrm{MgO}\right)$ is 0.94 for the Bodom granites and 0.87 for the Obbnäs granites. In the Finnish rapakivi granites this ratio varies from 0.79 to 1.00 (Rämö \& Haapala 1995). It should be noted, however, that there is a clear difference in the overall $\mathrm{Fe} / \mathrm{Mg}$ ratio between Bodom and Obbnäs, with a higher ratio in the former. The hybrid granitoids shown in Fig. 9 are excluded from the averages above; averages for the different granitoid types are given in Table 1.

\section{Trace elements}

The average trace element composition of the Bodom and Obbnäs granites and the porphyritic hybrid granitoids are given in Table 2. Rapakivi granites by definition have the geochemical characteristics of A-type granites (Haapala \& Rämö 1992), which include high contents of high field strength elements such as $\mathrm{Ga}, \mathrm{Zr}$, and REE (excluding Eu), high F content, and high $\mathrm{Ga} / \mathrm{Al}, \mathrm{Rb} /$ $\mathrm{Ba}$ and $\mathrm{Rb} / \mathrm{Sr}$ (Whalen et al. 1987, Rämö 1991). The trace element contents are generally higher in the Bodom granites than in the porphyritic hornblende-biotite granite of Obbnäs (Fig. 10), but there are two important exceptions: $\mathrm{Ba}$ and $\mathrm{Sr}$. The average $\mathrm{Rb} / \mathrm{Ba}$ and $\mathrm{Rb} / \mathrm{Sr}$ of the Bodom granites are 0.44 and 3.14 , while the values for the porphyritic hornblende-biotite granite of Obbnäs are considerably lower, 0.14 and 0.89. Rämö and Haapala (1995, Table 2) presented area-weighted mean composition of rapakivi granites of the $\mathrm{Wi}$ borg and Laitila batholiths and reported $\mathrm{Rb} / \mathrm{Ba}$ of 0.24 and 0.23 , and $\mathrm{Rb} / \mathrm{Sr}$ of 2.23 and 2.50, respectively. They also presented the mean composition of different granite types of the Suomenniemi batholith, where $\mathrm{Rb} / \mathrm{Ba}$ and $\mathrm{Rb} / \mathrm{Sr}$ vary from 0.13 and 1.26 in hornblende granite to 3.45 and 26.5 in topaz-bearing granite. The values for $\mathrm{Rb} / \mathrm{Ba}$ and $\mathrm{Rb} / \mathrm{Sr}$ of the Bodom granites settle between the values for the biotite-hornblende and biotite granites of Suomenniemi, as does the average $\mathrm{SiO}_{2}$ content. The $\mathrm{Rb} / \mathrm{Ba}$ of the Obbnäs granite resembles the average value for the hornblende granite of Suomenniemi (lower $\mathrm{SiO}_{2}$ than in the Obbnäs granite), but the $\mathrm{Rb} / \mathrm{Sr}$ is clearly lower in the former.

The difference in the fluorine content of the Bodom and Obbnäs granites is also noteworthy. In the Bodom granites, the amount of fluorine varies from 1300 to $6600 \mathrm{ppm}$, with an average of $3400 \mathrm{ppm}$, while the porphyritic hornblendebiotite granite of Obbnäs contains only 200 to $1700 \mathrm{ppm}$ fluorine, the average being as low as 1111 ppm (Table 2, Fig. 10). As the highest amounts of fluorine are usually encountered in highly fractionated, high-silica rapakivi granites, the Obbnäs granite could be expected to contain a lower amount of fluorine than the more evolved Bodom granites. However, the porphyritic hornblende granite of Bodom, with a lower average $\mathrm{SiO}_{2}$ than the Obbnäs granite, also contains a clearly higher amount of fluorine, $1750 \mathrm{ppm}$ on the average. In the mean compositions of the $\mathrm{Wi}$ borg and Laitila rapakivi granites and the hornblende and biotite-hornblende granites of the Suomenniemi complex, with $\mathrm{SiO}_{2}$ contents lower than in the Obbnäs granite or close to it, the amount of fluorine is 1900 to 2600 ppm (Rämö \& Haapala 1995, Table 2), again considerably higher than in the Obbnäs granite.

The average trace element composition of the hybrid granitoids differs from that of the porphyritic hornblende-biotite granite of Obbnäs (Fig. 10). The higher amounts of $\mathrm{Ba}$ and $\mathrm{Sr}$ in the hybrid granites suggest that the anomalously high $\mathrm{Ba}$ and $\mathrm{Sr}$ contents of the Obbnäs granite could also be explained by mixing, especially because the contact between the hybrid granitoids and the actual granite is gradational. High $\mathrm{Ba}$ and $\mathrm{Sr}$ contents are, however, found also in samples from the northern half of the pluton where no clear evidence of mixing is present. Also, the low amount 
BODOM

a) $\mathrm{A} / \mathrm{CNK}$

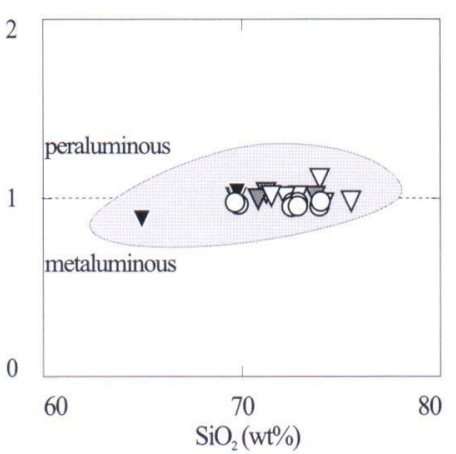

b) $\mathrm{Na}_{2} \mathrm{O}+\mathrm{K}_{2} \mathrm{O}(\mathrm{wt} \%)$

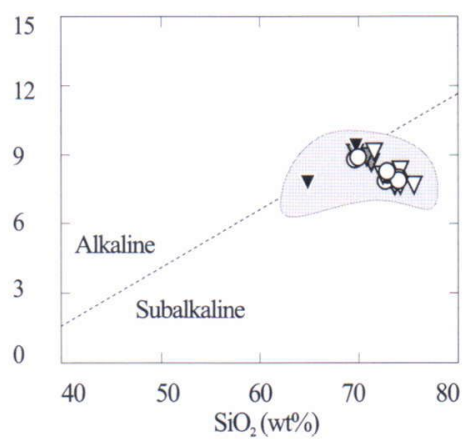

c) $\mathrm{FeO}_{\mathrm{TOT}} /\left(\mathrm{FeO}_{\mathrm{TOT}}+\mathrm{MgO}\right)$ (wt \%)

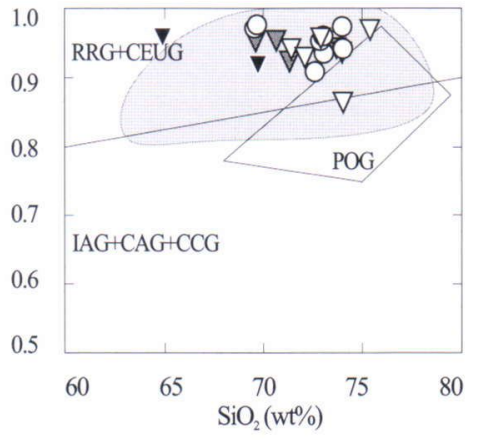

Finnish rapakivi granites

\section{Bodom}

v Porphyritic hornblende granite

- Porphyritic homblende-biotite granite

$\nabla$ Porphyritic biotite granite

o Even-grained granite
OBBNÄS
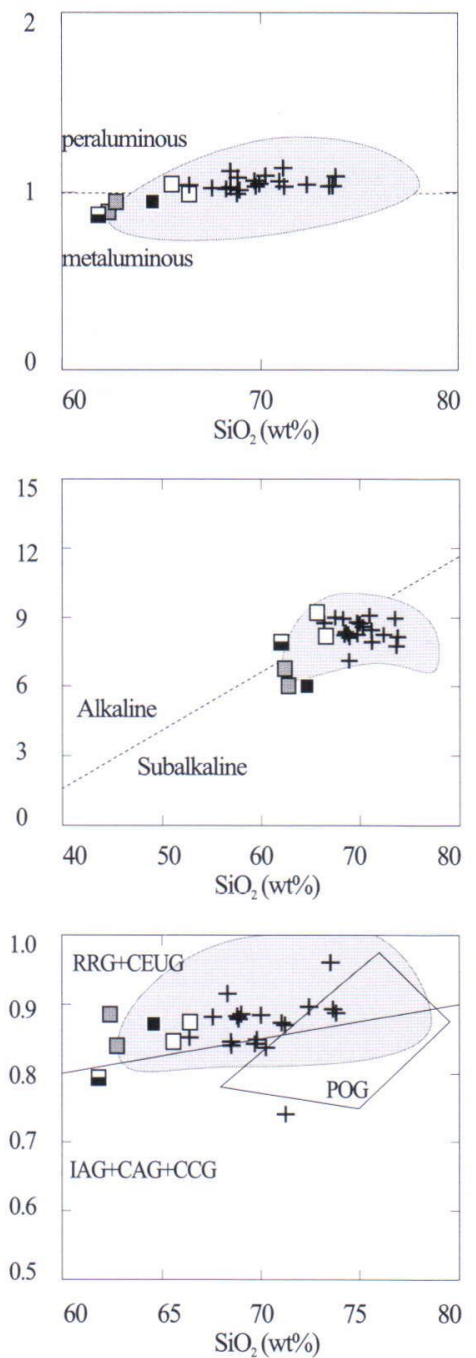

Obbnäs

- Even-grained hybrid granitoid

$\square$ Sparsely porphyritic hybrid granitoid

$\square$ Densely porphyritic hybrid granitoid

- Magmatic microgranular enclave in porphyritic homblende-biotite granite

+ Porphyritic hornblende-biotite granite

Fig. 9. Bodom and Obbnäs granites and the hybrid granitoids plotted in a) $\mathrm{A} / \mathrm{CNK} v \mathrm{vs}$. $\mathrm{SiO}_{2}$, b) $\mathrm{K}_{2} \mathrm{O}+\mathrm{Na}_{2} \mathrm{O} v \mathrm{~s}$. $\mathrm{SiO}_{2}$, and c) $\mathrm{FeO}_{\text {to }} /\left(\mathrm{FeO} \mathrm{tot}_{\text {tot }}+\mathrm{MgO}\right)$ vs. $\mathrm{SiO}_{2}$ variation diagrams. The line separating the alkaline and subalkaline fields in b) is from Irvine and Baragar (1971). The fields in c) are from Maniar and Piccoli (1989): RRG - riftrelated granitoids, CEUG - continental epeirogenic uplift granitoids, POG - post-orogenic granitoids, IAG island arc granitoids, CAG - continental arc granitoids, CCG - continental collision granitoids. Data for the Finnish rapakivi granite fields as in Fig. 7. 
Table 2. Average trace element compositions of the Bodom and Obbnäs granites and the porphyritic hybrid granitoids*

\section{BODOM}

Porphyritic granites

Hbl-granite Hbl-bt-granite Bt-granite

\section{OBBNÄS}

\section{Even-grained Porphyritic hbl-} granite bt-granite

\section{Densely}

porphyr.

hybrid

granitoid

$(\mathrm{n}=19)$

$(\mathrm{n}=2)$

$1111 \pm 407 \quad 1105 \pm 700$

$239 \pm 81$

$1449 \pm 590$

$159 \pm 22$

$215 \pm 78$

$55 \pm 16$

$432 \pm 113$

$24 \pm 6$

$20 \pm 12$

$38 \pm 5$

$25 \pm 2$

$68 \pm 19$

$105 \pm 18$

$9.0 \pm 2.0$

$11.0 \pm 1.6$

$4.3 \pm 1.0$

$1.7 \pm 0.4$

$2.8 \pm 0.4$

$3.5 \pm 0.4$

$4.47 \pm 0.79$

$4.08 \pm 0.18$

$0.19 \pm 0.09$

$1.68 \pm 0.44$

$1.14 \pm 0.34$

$169.50 \pm 36.06$

$328.50 \pm 54.45$

$38.65 \pm 5.30$

$147.00 \pm 9.90$

$27.20 \pm 2.97$

$4.55 \pm 0.57$

$24.65 \pm 3.32$

$3.68 \pm 0.88$

$18.95 \pm 6.29$

$3.44 \pm 1.07$

$9.51 \pm 3.67$

$1.38 \pm 0.59$

$7.96 \pm 2.89$

$1.26 \pm 0.60$

$200.25 \pm 32.08$

$376.75 \pm 58.15$

$42.95 \pm 6.65$

$151.75 \pm 26.51$

$25.20 \pm 4.20$

$3.04 \pm 0.84$

$22.58 \pm 4.78$

$3.13 \pm 0.63$

$15.00 \pm 3.40$

$2.74 \pm 0.57$

$7.19 \pm 1.48$

$0.95 \pm 0.16$

$5.59 \pm 0.88$

$0.80 \pm 0.14$

$24.25 \pm 1.05$

$0.38 \pm 0.03$
$22.0 \pm 9.0$

$10.5 \pm 2.3$

$7.1 \pm 2.0$

$0.9 \pm 0.2$

$2.8 \pm 0.9$

$0 \pm 0.4$

$5.8 \pm 3.1$

$4.22 \pm 0.30$

$0.46 \pm 0.29$

$3.22 \pm 1.30$

$143.63 \pm 37.59$

$276.67 \pm 64.40$

$31.68 \pm 9.76$

$110.45 \pm 38.73$

$19.78 \pm 7.46$

$1.71 \pm 0.57$

$18.27 \pm 7.31$

$2.71 \pm 1.16$

$13.82 \pm 6.49$

$2.68 \pm 1.29$

$7.33 \pm 3.32$

$1.02 \pm 0.43$

$6.27 \pm 2.28$

$0.90 \pm 0.30$

$16.58 \pm 5.04$

$0.29 \pm 0.10$
$3.37 \pm 0.26$

$0.14 \pm 0.10$

$0.89 \pm 0.46$

$4.32 \pm 1.10$

$291.13 \pm 43.70$

$566.75 \pm 71.99$

$64.89 \pm 7.88$

$234.63 \pm 28.94$

$39.61 \pm 5.31$

$2.81 \pm 0.46$

$35.38 \pm 5.14$

$4.88 \pm 0.72$

$24.09 \pm 4.38$

$4.29 \pm 0.73$

$11.06 \pm 1.77$

$1.45 \pm 0.23$

$8.64 \pm 1.33$

$1.18 \pm 0.18$

$23.04 \pm 3.61$

$0.23 \pm 0.03$
$117.32 \pm 58.35$

$230.26 \pm 110.74$

$26.01 \pm 11.65$

$92.22 \pm 37.53$

$15.54 \pm 5.37$

$2.32 \pm 0.67$

$14.14 \pm 4.60$

$1.94 \pm 0.60$

$9.42 \pm 2.74$

$1.75 \pm 0.49$

$4.64 \pm 1.21$

$0.61 \pm 0.16$

$3.84 \pm 0.90$

$0.55 \pm 0.12$

$20.40 \pm 7.73$

$0.52 \pm 0.22$
$365 \pm 233$

$2283 \pm 421$

$157 \pm 25$

$316 \pm 6$

$53 \pm 8$

$521 \pm 18$

$31 \pm 5$

$11 \pm 0$

$25 \pm 18$

$27 \pm 1$

$80 \pm 27$

$27.5 \pm 13.4$

$11.0 \pm 1.4$

$8.8 \pm 2.8$

$1.8 \pm 0.1$

$3.32 \pm 0.21$

$0.07 \pm 0.00$

$0.50 \pm 0.07$

$121.00 \pm 12.73$

$231.00 \pm 9.90$

$26.05 \pm 0.21$

$94.10 \pm 1.41$

$15.65 \pm 0.35$

$3.20 \pm 0.11$

$14.80 \pm 0.42$

$2.09 \pm 0.02$

$10.20 \pm 0.14$

$1.93 \pm 0.04$

$5.05 \pm 0.06$

$0.71 \pm 0.01$

$4.28 \pm 0.25$

$0.65 \pm 0.08$

$19.20 \pm 3.15$

$0.63 \pm 0.04$
Sparsely

porphyr.

hybrid

granitoid

$(\mathrm{n}=2)$

$\left(\mathrm{Eu} / \mathrm{Eu}^{*}\right)_{\mathrm{N}} \quad 0.53 \pm 0.00$

* The analytical data is available from the author by request.

$\mathrm{Ga} / \mathrm{Al}=10000 * \mathrm{Ga} / \mathrm{Al}_{2} \mathrm{O}_{3} * 0.5292$; conversion factor for $\mathrm{Al}_{2} \mathrm{O}_{3}$ according to Ragland (1989)

$(\mathrm{La} / \mathrm{Yb})_{\mathrm{N}}$ and $\left(\mathrm{Eu} / \mathrm{Eu}^{*}\right)_{\mathrm{N}}$ are chondrite-normalized ratios; normalizing values according to

Taylor and McLennan (1985) 


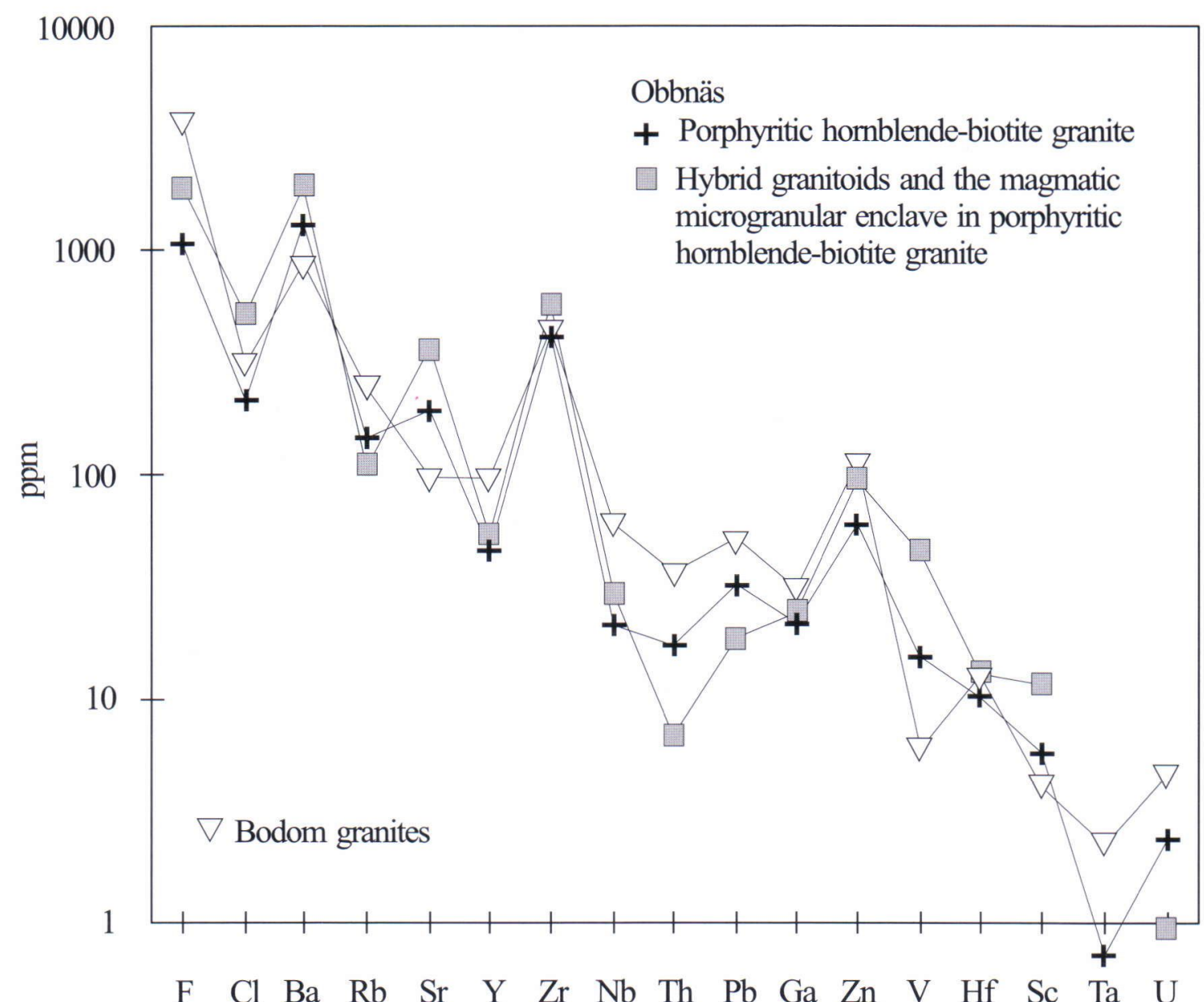

Fig. 10. A spiderogram showing average trace element compositions (ppm) of the Bodom and Obbnäs granites and the hybrid granitoids.

of fluorine in the hornblende-biotite granite cannot be explained by mixing, as the fluorine contents are higher in the hybrid granites, and thus mixing would have elevated the fluorine content in the granite instead of lowering it.

Despite the peculiarities in the trace element composition, the porphyritic hornblende-biotite granite of Obbnäs plots into the A-type granite field in the $\mathrm{Ga} / \mathrm{Al}$-discrimination diagrams, together with the hybrid granitoids and the Bodom granites (Figs. 11a and 11b). The Ga/Al-ratio varies from 3.78 to 5.22 in the Bodom pluton, where the highest values are encountered in the even-grained granite (averages are given in Table 2). In the rocks of Obbnäs the ratio is slightly lower, 3.01 to 4.18 in the porphyritic hornblende-biotite granite and 2.46 to 4.09 in the hybrid granitoids, but still high enough to set them apart from S-, M-, and I-type granites. Also, the high $\mathrm{Zr}-, \mathrm{Nb}-, \mathrm{Ce}-$, and Y-content of the Bodom and Obbnäs rocks separates them from highly fractionated, non-peralkaline I- or S-type granites, which can have geochemical features resembling the A-type (Figs. $11 \mathrm{c}$ and $11 \mathrm{~d})$.

In the tectonic discrimination diagrams of Pearce et al. (1984), the Bodom and Obbnäs granites plot into the field of within-plate granites of attenuated continental crust (Fig. 12); the Finnish 
a)

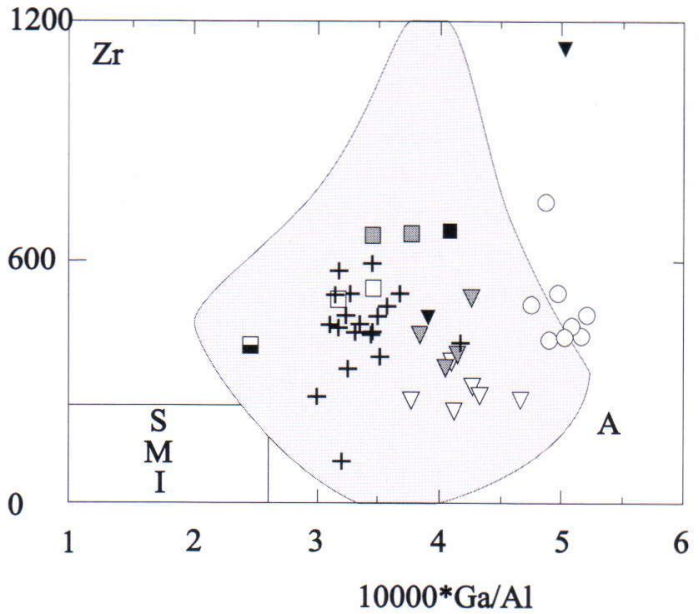

c)

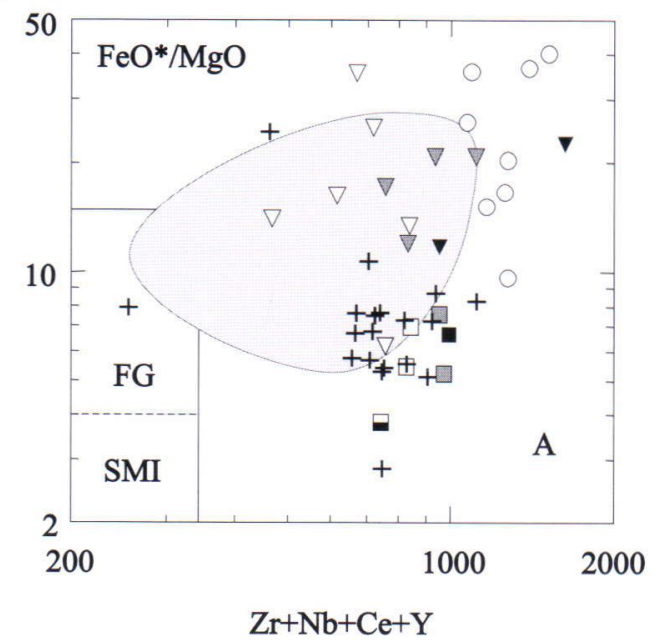

b)

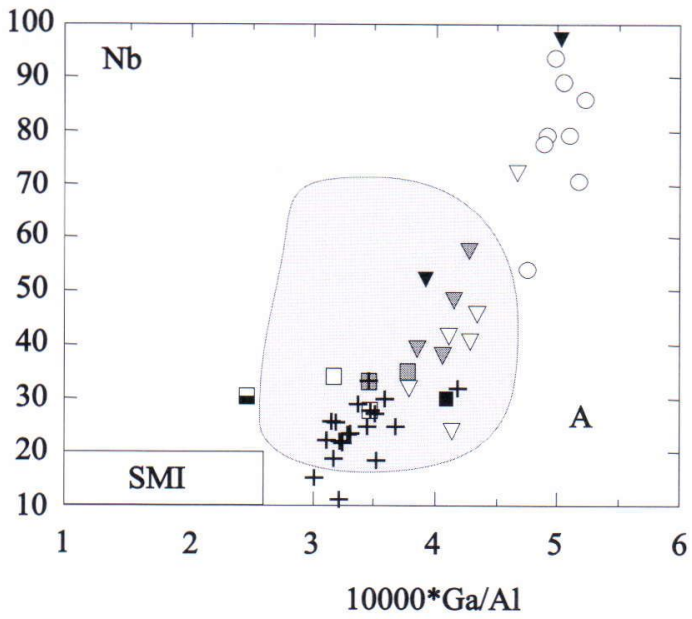

d)

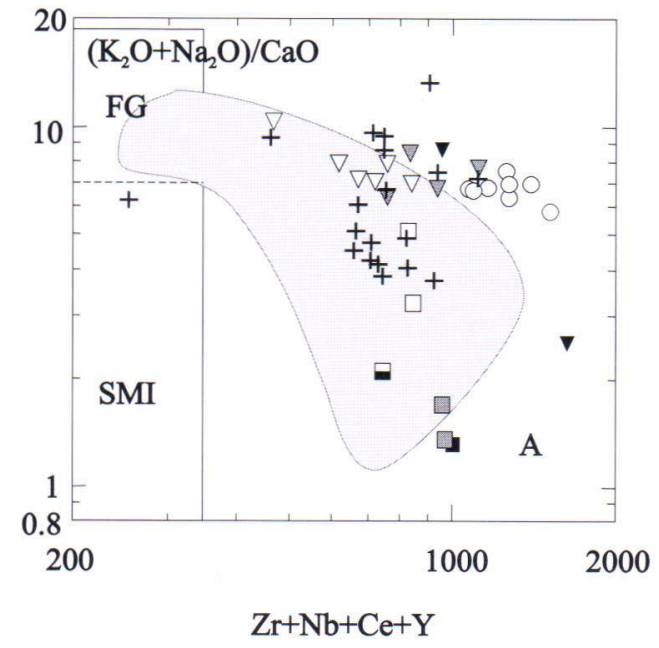

Finnish rapakivi granites

Bodom

v Porphyritic hormblende granite

* Porphyritic hornblende-biotite granite

$\nabla$ Porphyritic biotite granite

o Even-grained granite
Obbnäs

- Even-grained hybrid granitoid

\ Sparsely-porphyritic hybrid granitoid

$\square$ Densely-porphyritic hybrid granitoid

- Magmatic microgranular enclave in porphyritic hornblende-biotite granite

+ Porphyritic homblende-biotite granite

Fig. 11. Bodom and Obbnäs granites and the hybrid granitoids plotted in a) $\mathrm{Zr} v$ s. $\left.1000{ }^{*} \mathrm{Ga} / \mathrm{Al}, \mathrm{b}\right) \mathrm{Nb}$ vs. $10000 * \mathrm{Ga} / \mathrm{Al}$, c) $\mathrm{FeO}_{\text {to }} / \mathrm{MgO}$ vs. $\mathrm{Zr}+\mathrm{Nb}+\mathrm{Ce}+\mathrm{Y}$, and d) $\left(\mathrm{K}_{2} \mathrm{O}+\mathrm{Na}_{2} \mathrm{O}\right) / \mathrm{CaO}$ vs. $\mathrm{Zr}+\mathrm{Nb}+\mathrm{Ce}+\mathrm{Y}$ discrimination diagrams of Whalen et al. (1987). Data for the Finnish rapakivi granite fields as in Fig. 7.

in the Bodom and Obbnäs plutons. From the chondrite-normalized averages in Fig. 13a and from the average amounts given in Table 2 , it can be seen that the Bodom granites contain higher amounts of the REE than the porphyritic hornblende-biotite granite of Obbnäs. Also, the REE content of the 
a)

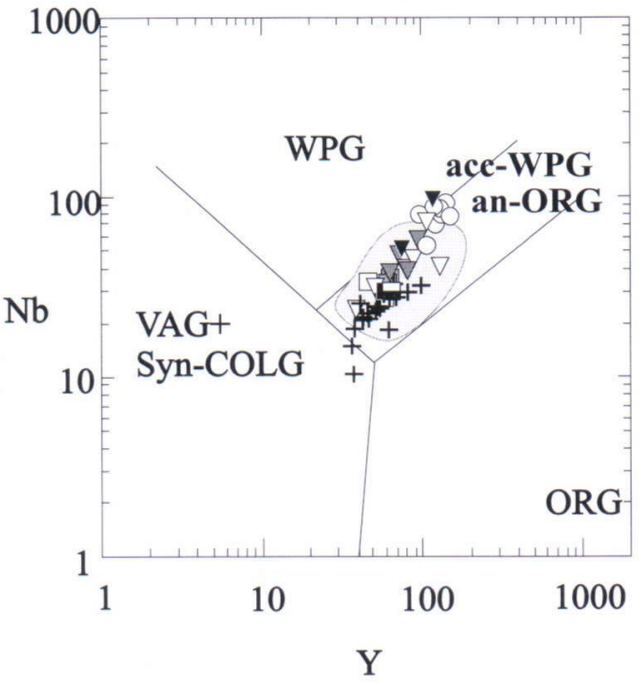

b) 2000

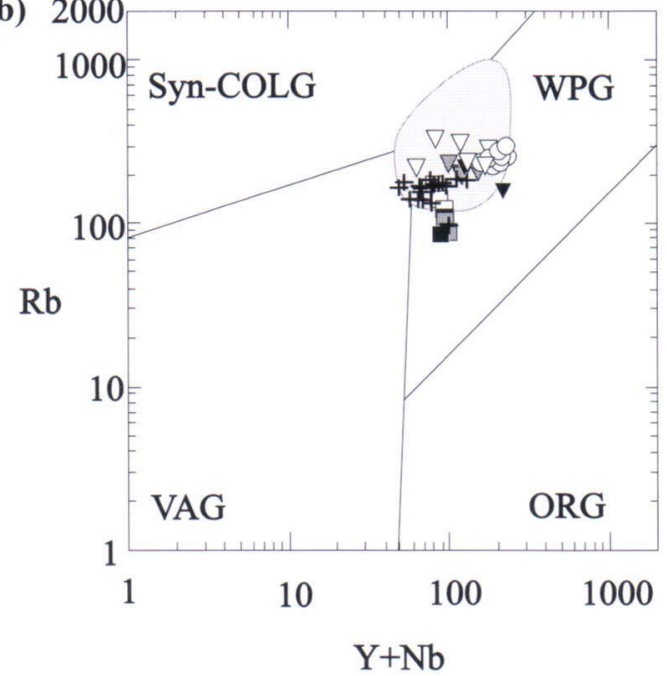

Obbnäs

- Even-grained hybrid granitoid

$\square$ Sparsely-porphyritic hybrid granitoid

$\square$ Densely-porphyritic hybrid granitoid

- Magmatic microgranular enclave

in porphyritic hornblende-biotite granite

+ Porphyritic hornblende-biotite granite

Fig. 12. Bodom and Obbnäs granites and the hybrid granitoids plotted in a) Nbvs. $Y$, and b) Rb vs. Y+Nb tectonic discrimination diagrams of Pearce et al. (1984). WPG - within-plate granites, acc-WPG-attenuated continental crust within-plate granites, VAG - volcanic arc granites, syn-COLG - syn-collision granites, ORG ocean ridge granites, an-ORG - anomalous ocean ridge granites. Data for the Finnish rapakivi granite fields as in Fig. 7.

even-grained Bodom granite is distinctly higher than those of the porphyritic Bodom granites, which supports the idea suggested by the field observations of a separate intrusion phase. All the patterns show a strong LREE-enrichment: the average $(\mathrm{La} / \mathrm{Yb})_{\mathrm{N}}$ is 19.0 for the porphyritic Bodom granites, 23.0 for the even-grained Bodom granite, and 20.4 for the porphyritic hornblende-biotite granite of Obbnäs. The average $\mathrm{Eu} / \mathrm{Eu} *$ for the porphyritic Bodom granites is 0.36 , and the increase in the depth of the anomaly from the hornblende granite to biotite granite (see Table 2) agrees with the idea of a single fractionation series. The strongest Eu-depletion is found in the even-grained Bodom granite, for which the average $\mathrm{Eu} / \mathrm{Eu}^{*}$ is 0.23 . The porphyritic hornblendebiotite granite of Obbnäs has a weaker Eu-anom- aly, average $\mathrm{Eu} / \mathrm{Eu}^{*} 0.52$, in line with the more primitive character of the rock. The average (La/ $\mathrm{Yb})_{\mathrm{N}}$ and $\mathrm{Eu} / \mathrm{Eu} *$ of the Finnish rapakivi granites are 9.24 and 0.26 , respectively (Rämö \& Haapala 1995). The smaller $(\mathrm{La} / \mathrm{Yb})_{\mathrm{N}}$ value and the pronounced negative Eu-anomaly reflect the presence in several Finnish rapakivi suites of highly fractionated, topaz-bearing granites, which characteristically show a flat chondrite-normalized pattern with a strong Eu-depletion. The representative samples of the hornblende and biotite granites of the Suomenniemi complex (Rämö 1991) have REE patterns fairly similar to the Obbnäs and Bodom granites (Fig. 13a).

The hybrid granitoids (including the magmatic microgranular enclave) are slightly enriched in HREE in comparison to the porphyritic horn- 
a) 1000

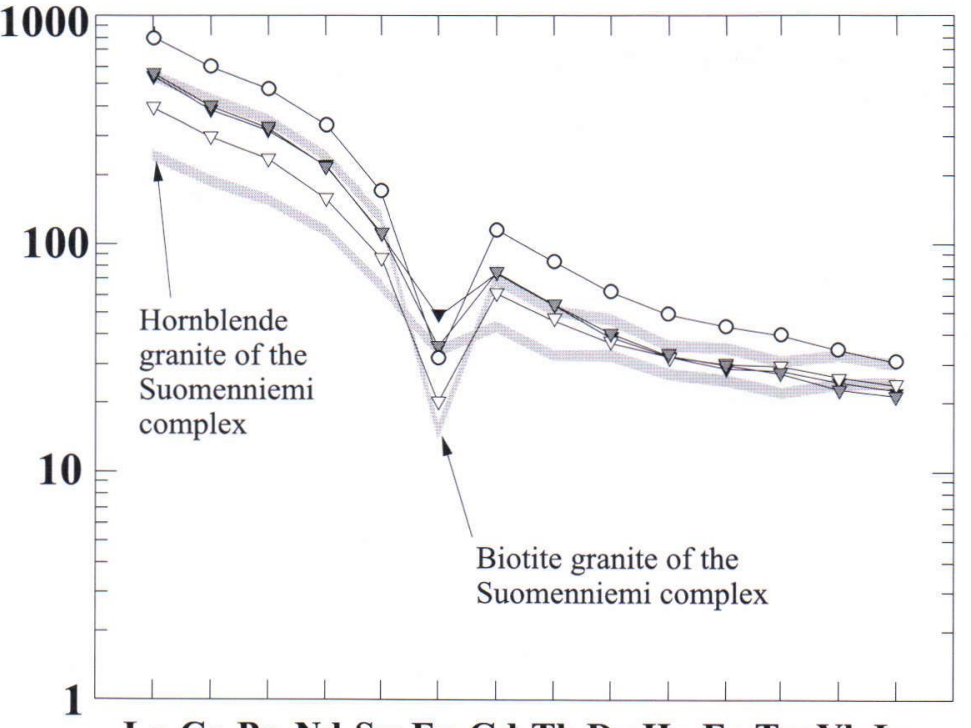

La Ce Pr Nd SmEu Gd Tb Dy Ho Er Tm Yb Lu

b)

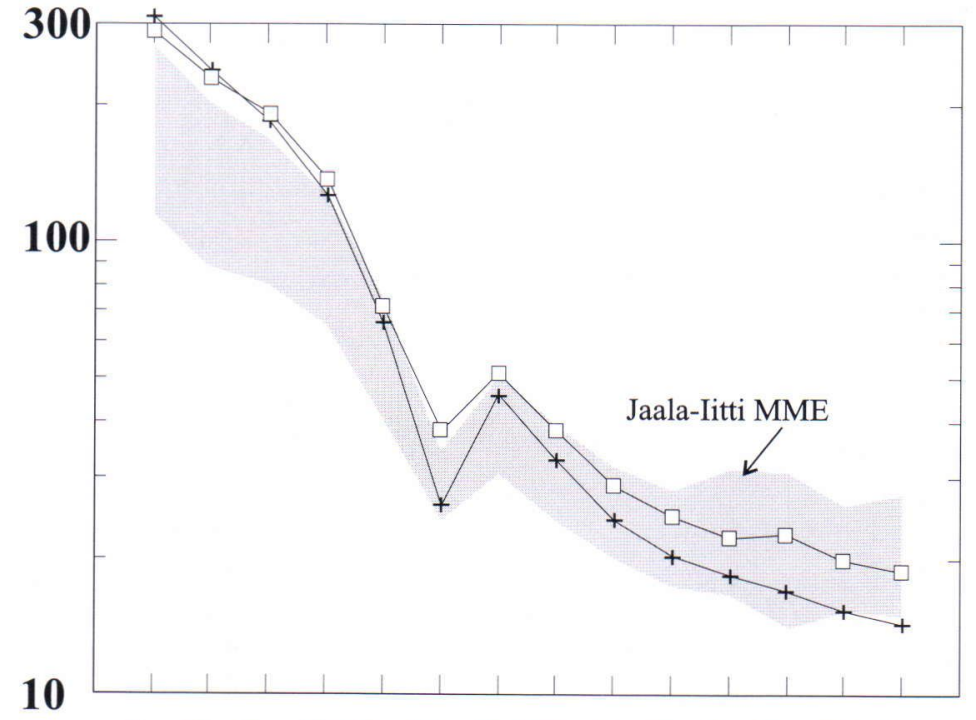

La Ce Pr Nd Sm Eu Gd Tb Dy Ho Er Tm Yb Lu
Bodom

จ Porphyritic homblende granite

$\nabla$ Porphyritic hornblende-biotite granite

$\nabla$ Porphyritic biotite granite

○ Even-grained granite

\section{Obbnäs}

$\square$ Hybrid granitoids and the magmatic microgranular enclave in porphyritic homblende-biotite granite

+ Porphyritic homblende-biotite granite

Fig. 13. Average chondrite-normalized REE contents of a) the Bodom and Obbnäs granites compared to representative samples of the rapakivi granites of the Suomenniemi complex (Rämö 1991), and b) the porphyritic hornblende-biotite granite and the hybrid granitoids of Obbnäs compared to the magmatic mafic enclaves (MME) of the Jaala-Iitti complex (Salonsaari 1995). The normalizing values according to Taylor and McLennan (1985).

blende-biotite granite of Obbnäs and have a smaller negative Eu-anomaly (Fig. 13b): the average $(\mathrm{La} / \mathrm{Yb})_{\mathrm{N}}$ for the hybrid granitoids is 15.2 and $\mathrm{Eu} /$ $\mathrm{Eu}^{*}$ is 0.62 . The chondrite-normalized average
REE patterns of the rocks of the Obbnäs pluton resemble the patterns of the hybrid rocks (MME) of the Jaala-Iitti complex (Salonsaari 1995). 


\section{DISCUSSION}

According to Sederholm (1926), the Bodom and Obbnäs granites do not have a clear petrogenetic relation with either the Svecofennian granites or the rapakivi granites of southeastern Finland. The foliation observed especially in the Obbnäs granite was the main reason why he thought the two plutons were somewhat older than the rapakivi granites as the latter seldom show clear foliation. The U-Pb age data by Vaasjoki (1977), however, together with the fact that the non-magmatic foliation in the plutons can be attributed to deformation in the Porkkala-Mäntsälä shear zone (Elminen 1999), makes it unnecessary to distinguish the Bodom and Obbnäs granites from the rapakivi granites of Finland. Also, these two plutons show the petrographic and geochemical features typical of rapakivi granites in Finland and elsewhere.

Even though both the Bodom and Obbnäs granites can be classified as rapakivi granites according to the definition by Haapala and Rämö (1992), there are some features that require further consideration - variation in the contents of $\mathrm{Ba}, \mathrm{Rb}$, and $\mathrm{Sr}$ in particular. The two plutons are situated rather close to each other and include porphyritic granites that show many features in common, so the possibility that their granites are related to each other by fractional crystallization must be considered. In this scenario the Bodom and Obbnäs granites could represent two different levels of one initial pluton, now exposed and torn apart by movements along the Porkkala-Mäntsälä shear zone. The more primitive Obbnäs granite would represent lower parts of this hypothetical pluton, and the more evolved Bodom granites its upper parts. The porphyritic hornblende-biotite granite of Obbnäs contains ca. 70 wt $\% \mathrm{SiO}_{2}, 1450 \mathrm{ppm}$ $\mathrm{Ba}, 160 \mathrm{ppm} \mathrm{Rb}$, and $220 \mathrm{ppm} \mathrm{Sr}$, on average. The porphyritic hornblende-biotite granite of Bodom is slightly more silicic, with average $\mathrm{SiO}_{2}$ of 71 wt\%, Ba 1310 ppm, Rb 210 ppm, and Sr $130 \mathrm{ppm}$. Two models (Table 3 ) involving fractional crystallization (Rayleigh fractionation) of slightly different mineral assemblages (granitic and granodioritic) were used to define the degree of fractionation that would produce a melt with $\mathrm{Ba}, \mathrm{Rb}$, and $\mathrm{Sr}$ contents similar to the porphyritic hornblende-biotite granite of Bodom from a melt with the contents similar to the porphyritic hornblende-biotite granite of Obbnäs. Five-percent fractionation of the granitic assemblage (model 1) produces $\mathrm{Ba}$ contents close to the value of the Bodom granite; the slightly more mafic, granodioritic mineral assemblage (model 2 ) requires a somewhat higher degree of crystallization $(7 \%)$. Clearly higher degrees of fractionation are required to produce $\mathrm{Rb}$ and $\mathrm{Sr}$ contents similar to those in the Bodom granite $(33 \%$ and $24 \%$ in model 1 , and $35 \%$ and $31 \%$ in model 2 , respectively). Thus the observed differences in the $\mathrm{Ba}$, $\mathrm{Rb}$, and $\mathrm{Sr}$ contents of the porphyritic hornblendebiotite granites of Obbnäs and Bodom cannot be explained by simple fractional crystallization.

According to Beard et al. (1993), the most important factor in producing recognizable signatures in $\mathrm{Ba}, \mathrm{Eu}, \mathrm{K} / \mathrm{Ba}$, and $\mathrm{Ba} / \mathrm{Rb}$ is the relative stability of $\mathrm{K}$-feldspar during partial melting. Their melting experiments showed that partial melting of a source in which potassium-rich feldspar is stable (granodioritic starting material) will produce granitic, metaluminous to slightly peraluminous melts with low $\mathrm{Ba}$ and $\mathrm{Ba} / \mathrm{Rb}$, high $\mathrm{K} / \mathrm{Ba}$, and large negative Eu-anomalies. When potassium-rich feldspar is not present in the restite (dioritic starting material) the melts will be granitic, strongly metaluminous, enriched in $\mathrm{CaO}, \mathrm{TiO}_{2}, \mathrm{MgO}$, and $\mathrm{FeO}$, and depleted in $\mathrm{SiO}_{2}$ and $\mathrm{K}_{2} \mathrm{O}$ compared to the melts of the granodiorite, and will have high Ba contents. These observations match the chemical features of the Bodom and Obbnäs granites: compared to the Bodom granites, the Obbnäs granite has higher contents of $\mathrm{Ba}$ and $\mathrm{Sr}$, is enriched in $\mathrm{CaO}, \mathrm{TiO}_{2}, \mathrm{MgO}$, and $\mathrm{FeO}$, depleted in $\mathrm{SiO}_{2}$ and $\mathrm{K}_{2} \mathrm{O}$ (see Fig. 8), and has a relatively small Eu-depletion (see Fig. 13). Thus, derivation from compositionally different sources seems to provide an explanation to the observed chemical differences between the two plutons. Possible source compositions might be granodioritic (Bodom pluton) and tonalitic or quartz dioritic rather than dioritic (Obbnäs pluton), considering the metaluminous to slightly peraluminous character of the Bodom and 
Table 3. Behavior of $\mathrm{Ba}, \mathrm{Rb}$, and Sr during fractional crystallization of two slightly different mineral assemblages (granitic and granodioritic) from a parent melt with composition similar to the porphyritic hornblendebiotite granite of Obbnäs.

\begin{tabular}{|c|c|c|c|}
\hline & & Model 1 (granitic) & Model 2 (granodioritic) \\
\hline $\begin{array}{l}\text { Crystallizing } \\
\text { mineral } \\
\text { assemblage }\end{array}$ & & $\begin{array}{c}15 \% \text { quartz, } 34 \% \text { alkali } \\
\text { feldspar, } 34 \% \text { plagioclase, } \\
10 \% \text { hornblende, } 7 \% \text { biotite }\end{array}$ & $\begin{array}{c}15 \% \text { quartz, } 18 \% \text { alkali } \\
\text { feldspar, } 35 \% \text { plagioclase, } \\
20 \% \text { hornblende, } 12 \% \text { biotite }\end{array}$ \\
\hline $\begin{array}{l}\mathrm{Ba} \\
\mathrm{D} \\
\mathrm{Sr}\end{array}$ & $\mathrm{Rb}$ & $\begin{array}{l}2.87 \\
0.29 \\
2.83\end{array}$ & $\begin{array}{l}2.39 \\
0.35 \\
2.28\end{array}$ \\
\hline $\begin{array}{l}\mathrm{Ba} \\
\mathrm{C}_{0}(\mathrm{ppm}) \\
\mathrm{Sr}\end{array}$ & $\mathrm{Rb}$ & $\begin{array}{c}1449 \\
159 \\
215\end{array}$ & $\begin{array}{c}1449 \\
159 \\
215\end{array}$ \\
\hline
\end{tabular}

\begin{tabular}{l|ccc|ccc} 
& \multicolumn{3}{|c|}{$\begin{array}{c}\text { Fractional crystallization } \\
\text { (Rayleigh fractionation) } \\
\mathrm{C}=\mathrm{C}_{0} \mathrm{~F}^{(\mathrm{D}-1)}(\mathrm{ppm})\end{array}$} & \multicolumn{3}{c}{$\mathrm{C}=\mathrm{C}_{0} \mathrm{~F}^{(\mathrm{D}-1)}(\mathrm{ppm})$} \\
\hline $\mathrm{F}$ & $\mathrm{Ba}$ & $\mathrm{Rb}$ & $\mathrm{Sr}$ & $\mathrm{Ba}$ & $\mathrm{Rb}$ & $\mathrm{Sr}$ \\
0.95 & 1316 & 165 & 196 & 1349 & 164 & 201 \\
0.93 & 1265 & 167 & 188 & 1309 & 167 & 196 \\
0.76 & 867 & 193 & 130 & 989 & 190 & 151 \\
0.69 & 724 & 207 & 109 & 865 & 202 & 133 \\
0.67 & 685 & 211 & 103 & 830 & 206 & 129 \\
0.65 & 647 & 212 & 98 & 796 & 210 & 124
\end{tabular}

Determined average amounts of $\mathrm{Ba}, \mathrm{Rb}$, and $\mathrm{Sr}$ in the porphyritic hornblende-biotite granites of Obbnäs and Bodom

\begin{tabular}{l|c|c|c} 
& $\mathrm{Ba}(\mathrm{ppm})$ & $\mathrm{Rb}(\mathrm{ppm})$ & $\mathrm{Sr}(\mathrm{ppm})$ \\
\hline Obbnäs $\left(\mathrm{C}_{0}\right)$ & 1449 & 159 & 215 \\
Bodom (C) & 1309 & 211 & 131
\end{tabular}

$\mathrm{D}$ is the bulk partition coefficient. The mineral/melt partition coefficients used in the calculation of $\mathrm{D}$ are from Rollinson (1993, Table 4.3).

$\mathrm{C}_{0}$ is the trace element abundance in the parent melt (equal to the porphyritic hbl-bt granite of Obbnäs).

$\mathrm{F}$ is the amount of the residual (daughter) melt.

$\mathrm{C}$ is the trace element abundance in the residual (daughter) melt (equal to the porphyritic hbl-bt granite of Bodom).

Obbnäs granites (see Fig. 9). Detailed quantitative modelling and isotopic studies of the Bodom and Obbnäs granites are currently under way and the results will be presented in a separate paper.

Accessory titanite is present in the porphyritic hornblende-biotite granite and the hybrid granitoids of the Obbnäs pluton, but it is rare in the other Finnish rapakivi granites (Laitakari et al. 1996). Some of the Proterozoic rapakivi granites elsewhere, for example the Wolf River batholith in Wisconsin, U.S.A. (Anderson 1980), the Jamon granite in Brazil (Dall'Agnol et al. 1997), and several of the Estonian rapakivi granites (Soesoo \&
Niin 1992, Laitakari et al. 1996) do contain accessory titanite. According to Dall'Agnol et al. (1997), the Jamon granite represents a magnetitebearing, more oxidized subgroup of the A-type granites, while the Finnish rapakivi granites, for example, belong to 'typical' ilmenite-bearing Atype granites. These authors further state that the differences in the oxygen fugacities of these two groups reflect differences in magma sources or in magmatic evolution. The presence of accessory titanite in the Obbnäs pluton suggests that it is more oxidized than the Bodom pluton in which rare titanite is found only in the porphyritic horn- 
blende granite. Also, the comparatively lower Fe$\mathrm{O}_{\text {tot }} /\left(\mathrm{FeO}_{\mathrm{tot}}+\mathrm{MgO}\right)$ in the Obbnäs granite is indicative of more oxidizing conditions during the magmatic evolution of the Obbnäs pluton, compared to that of the Bodom pluton and similar Finnish rapakivi granites. The Jamon and Musa granites of the Amazonian Craton also display Fe/Mg similar to those of the Obbnäs granite (Dall'Agnol et al. 1999). These observations are compatible with the idea of different sources for the Obbnäs and Bodom granites.

Interestingly enough, some of the Estonian rapakivi granites show features similar to the Obbnäs granite: they contain accessory titanite, have low contents of $\mathrm{F}$, high contents of $\mathrm{Ba}$, and a low $\mathrm{Rb} / \mathrm{Sr}$ (Soesoo \& Niin 1992, Kirs \& Petersell 1994, Rämö et al. 1996). Further work to find out the extent of these similarities, as well as their implications, is required.

\section{CONCLUSIONS}

The following conclusions can be made considering the granite plutons of Bodom and Obbnäs:

1. The mode of occurrence of the granites of the two plutons is typical of the Finnish rapakivi granites: they sharply crosscut the Paleoproterozoic (Svecofennian) metamorphic bedrock, and occasionally enclose fragments of these older rocks.

2. The Bodom pluton comprises two intrusion phases: a fractionation series of porphyritic granites (hornblende, hornblende-biotite, and biotite granite) and a slightly younger phase composed of even-grained granite.

3. The main rock type of the Obbnäs pluton is porphyritic hornblende-biotite granite, which becomes more mafic towards the southwestern part of the pluton. Three different types of hybrid rocks produced by magma mingling and mixing are found on the southernmost tip of the Obbnäs peninsula; in the southern part of the pluton the granite also contains magmatic microgranular enclaves.

4. The Bodom and Obbnäs granites are mainly composed of quartz, alkali feldspar (microcline) and plagioclase $\left(\mathrm{An}_{15-41}\right)$, with iron-rich biotite and/or amphibole (ferropargasite or hastingsite) as the mafic silicates. Accessory minerals include fluorite, zircon, allanite, apatite, oxides, and - in the Obbnäs pluton - titanite.

5. The Bodom and Obbnäs granites have the geochemical characteristics of subalkaline A-type granites. They are metaluminous to slightly peraluminous, with average A/CNK of 1.00 (Bodom) and 1.05 (Obbnäs). Fe/Mg is high for both the Bodom and Obbnäs granites: average $\mathrm{FeO}_{\text {tot }}$ l $\left(\mathrm{FeO}_{\text {tot }}+\mathrm{MgO}\right)$ is 0.94 and 0.87 , respectively. They also have high $\mathrm{Ga} / \mathrm{Al}$ and plot into the A-type granite field in the discrimination diagrams of Whalen et al. (1987). The REE contents are high with LREE-enriched chondrite-normalized patterns and moderate to relatively pronounced negative Eu-anomalies.

6. The differences in the $\mathrm{Ba}, \mathrm{Rb}$, and $\mathrm{Sr}$ contents of the porphyritic hornblende-biotite granites of Bodom and Obbnäs cannot be adequately explained by fractional crystallization of either granitic or granodioritic mineral assemblages, so the plutons are, most likely, separate intrusions with different sources.

7. Compared to the Bodom granites, the Obbnäs granite is partly enriched in $\mathrm{CaO}, \mathrm{TiO}_{2}, \mathrm{MgO}$, and $\mathrm{FeO}$, depleted in $\mathrm{SiO}_{2}$ and $\mathrm{K}_{2} \mathrm{O}$, contains high amounts of $\mathrm{Ba}$ and $\mathrm{Sr}$, and has a relatively small average negative Eu-anomaly. These features can be explained by different protoliths: a potassium feldspar-rich ( granodioritic) for the Bodom and a potassium feldspar-poor ( $\sim$ tonalitic or quartz dioritic) for the Obbnäs granites.

ACKNOWLEDGEMENTS. I wish to thank Professor Ilmari Haapala for initiating the study, Dr. Seppo Lahti for providing unpublished geochemical data, and Dr. O. Tapani Rämö for his expert advice. Professor Roberto Dall'Agnol and Dr. Ulf $B$. Andersson, to whom I offer my sincerest thanks, also provided useful comments and insights. The research was supported by the Academy of Finland. This paper is a contribution to IGCP Project 426 (Granite Systems and Proterozoic Lithospheric Processes). 


\section{REFERENCES}

Anderson, J.L. 1980. Mineral equilibria and crystallization conditions in the Late Precambrian Wolf River rapakivi massif, Wisconsin. American Journal of Science 280, 289-332.

Anderson, J.L. 1983. Proterozoic anorogenic granite plutonism of North America. Geological Society of America Memoir 161, 133-154.

Aro, K. \& Laitakari, I. (eds.) 1987. Suomen diabaasit ja muut mafiset juonikivilajit. Geological Survey of Finland, Report of Investigation 76. 254 p. (in Finnish, with abstracts in English)

Beard, J.S., Abitz, R.J. \& Lofgren, G.E. 1993. Experimental melting of crustal xenoliths from Kilbourne Hole, New Mexico and implications for the contamination and genesis of magmas. Contributions to Mineralogy and Petrology $115,88-102$.

Cantagrel, J.-M., Didier, J. \& Gourgaud, A. 1984. Magma mixing: origin of intermediate rocks and 'enclaves' from volcanism and plutonism. Physics of the Earth and Planetary Interiors 35, 63-76.

Dall'Agnol, R., Pichavant, M. \& Champenois, M. 1997. Iron-titanium oxide minerals of the Jamon granite, Eastern Amazonian Region, Brazil: Implications for the oxygen fugacity in Proterozoic, A-type granites. Anais da Academia Brasileira de Ciências 69/3, 325-347.

Dall'Agnoll, R., Rämö, O.T., Magalhães, M.S. \& Macambira, M.J.B. 1999. Petrology of the anorogenic, oxidized Jamon and Musa granites, Amazonian Craton: implications for the genesis of Proterozoic A-type granites. Lithos 46, 431-462.

De la Roche, H., Leterrier, J., Granclaude, P. \& Marchal M. 1980. A classification of volcanic and plutonic rocks using R1-R2 diagrams and major element analyses - its relationships and current nomenclature. Chemical Geology 29, 183-210.

Didier, J. 1987. Contribution of enclave studies to the understanding of origin and evolution of granitic magmas. Geologische Rundschau 76, 41-50.

Elminen, T. 1999. Porkkala-Mäntsälä -siirrosvyöhykkeen kuvaus ja tulkinta. Unpublished M.Sc. Thesis, University of Helsinki, 87 p. (in Finnish)

Haapala, I. 1977. Petrography and geochemistry of the Eurajoki stock, a rapakivi granite complex with greisen-type mineralization in southwestern Finland. Geological Survey of Finland, Bulletin 286. 128 p.

Haapala, I. \& Rämö, O.T. 1992. Tectonic setting and origin of the Proterozoic rapakivi granites of southeastern Fennoscandia. Transactions of the Royal Society of Edinburgh: Earth Sciences 83, 165-171.

Halonen, T.O. 1954. Bodomin graniitin petrologiasta. Unpublished M.Sc. Thesis, University of Helsinki, $50 \mathrm{p}$. (in Finnish)

Härme, M. 1960. Turku. General geological map of Finland 1: 400 000, Explanation to the map of rocks, Sheet B1. Geological Survey of Finland. 78 p.

Härme, M. 1969. Kerava. Geological map of Finland
1 : 100 000, Pre-Quaternary rocks, Sheet 2043. Geological Survey of Finland.

Härme, M. 1978. Keravan ja Riihimäen kartta-alueiden kallioperä. Summary: Precambrian rocks of the Kerava and Riihimäki map-sheet areas. Geological map of Finland $1: 100$ 000, Explanation to the maps of Pre-Quaternary rocks, Sheets 2043 and 2044. Geological Survey of Finland. $51 \mathrm{p}$.

Härme, M. 1980. Lahti - Helsinki. General geological map of Finland 1: 400 000, Explanation to the map of rocks, Sheet C1-D1. Geological Survey of Finland. 95 p.

Irvine, T.N. \& Baragar, W.R.A. 1971. A guide to the chemical classification of the common volcanic rocks. Canadian Journal of Earth Sciences 8, 523-548.

Kirs, J. \& Petersell, V. 1994. Age and geochemical character of plagiomicrocline granite veins in the Abja gabbro-dioritic massif. Acta et Commentationes Universitatis Tartuensis 972, 3-15.

Koistinen, T. (ed.) 1994. Precambrian basement of the Gulf of Finland and surrounding area, 1:1 mill. Espoo: Geological Survey of Finland.

Koistinen, T. (ed.) 1996. Explanation to the map of Precambrian basement of the Gulf of Finland and surrounding area 1:1 million. Geological Survey of Finland, Special Paper 21. 141 p.

Kosunen, P. 1998. Bodomin ja Obbnäsin rapakivigraniittien petrografia ja geokemia. Unpublished M.Sc. Thesis, University of Helsinki, 107 p. (in Finnish)

Laitakari, I., Rämö, T., Suominen, V., Niin, M., Stepanov, K. \& Amantov, A. 1996. Subjotnian: Rapakivi granites and related rocks in the surroundings of the Gulf of Finland. In: Koistinen, T. (ed.) Explanation to the Map of Precambrian basement of the Gulf of Finland and surrounding area 1:1 mill. Geological Survey of Finland, Special Paper 21, 59-97.

Laitala, M. 1960. Siuntio. Geological map of Finland $1: 100$ 000, Pre-Quaternary rocks, Sheet 2032. Geological Survey of Finland.

Laitala, M. 1961. Siuntio. Kallioperäkartan selitys. Summary: Explanation to the map of rocks. Geological map of Finland 1 : 100 000, Sheet 2032. Geological Survey of Finland. 32 p.

Laitala, M. 1994. Lohja. Geological map of Finland $1: 100$ 000, Pre-Quaternary rocks, Sheet 2041. Geological Survey of Finland.

Lokka, L. 1950. Chemical analyses of Finnish rocks. Bulletin de la Commission géologique de Finlande 151. $73 \mathrm{p}$.

Maniar, P.D. \& Piccoli, P.M. 1989. Tectonic discrimination of granitoids. Geological Society of America, Bulletin 101, 635-643.

Pearce, J.A., Harris, N.B.W. \& Tindle, A.G. 1984. Trace element discrimination diagrams for the tectonic interpretation of granitic rocks. Journal of Petrology 25, 956983.

Ragland, P.C. 1989. Basic Analytical Petrology. New York: Oxford University Press. 369 p.

Rieder, M., Haapala, I. \& Povondra, P. 1996. Mineralogy 
of dark mica from the Wiborg rapakivi batholith, southeastern Finland. European Journal of Mineralogy 8, 593605.

Rollinson, H. 1993. Using Geochemical Data: Evaluation, Presentation, Interpretation. Essex: Longman Scientific and Technical. $352 \mathrm{p}$.

Rämö, O.T. 1991. Petrogenesis of the Proterozoic rapakivi granites and the related basic rocks of southeastern Fennoscandia: $\mathrm{Nd}$ and $\mathrm{Pb}$ isotopic and general geochemical constraints. Geological Survey of Finland, Bulletin 335. $161 \mathrm{p}$.

Rämö, O.T. \& Haapala, I. 1995. One hundred years of rapakivi granite. Mineralogy and Petrology 52, 129-185.

Rämö, O.T., Huhma, H. \& Kirs, J. 1996. Radiogenic isotopes of the Estonian and Latvian rapakivi granite suites: new data from the concealed Precambrian of the East European Craton. Precambrian Research 79, 209-226.

Sahama, Th.G. 1945. On the chemistry of the East Fennoscandian rapakivi granites. Bulletin de la Commission géologique de Finlande 136, 15-67.

Salonsaari, P.T. 1995. Hybridization in the subvolcanic Jaala-Iitti complex and its petrogenetic relation to rapakivi granites and associated mafic rocks of Southeastern Finland. Bulletin of the Geological Society of Finland 67, Part 1b. 104 p.

Salonsaari, P.T. \& Haapala, I. 1994. The Jaala-Iitti rapakivi complex. An example of bimodal magmatism and hybridization in the Wiborg rapakivi batholith, Southeastern Finland. Mineralogy and Petrology 50, 21-34.
Savolahti, A. 1956. The Ahvenisto massif in Finland. The age of the surrounding gabbro-anorthosite complex and the crystallization of rapakivi. Bulletin de la Commission géologique de Finlande 174. 98 p.

Sederholm, J.J. 1926. On migmatites and associated PreCambrian rocks of southwestern Finland, Part II. Bulletin de la Commission géologique de Finlande 77. $143 \mathrm{p}$

Simonen, A. 1980. Suomen kallioperäkartta. Bedrock map of Finland 1: 1000 000. Geological Survey of Finland.

Soesoo, A. \& Niin, M. 1992. Petrographical and petrochemical features of the Estonian Precambrian porphyraceous potassium granites. Proceedings of the Estonian Academy of Science, Geology 41/3, 93-107.

Taylor, S.R. \& McLennan, S.M. 1985. The Continental Crust: its Composition and Evolution. Oxford: Blackwell. 312 p.

Vaasjoki, M. 1977. Rapakivi granites and other post-orogenic rocks in Finland. Their age and the lead isotopic composition of certain associated galena mineralizations. Geological Survey of Finland, Bulletin 294. 64 p.

Vorma, A. 1976. On the petrochemistry of rapakivi granites with special reference to the Laitila massif, southwestern Finland. Geological Survey of Finland, Bulletin $285.98 \mathrm{p}$.

Whalen, J.B., Currie, K.C. \& Chappell, B.W. 1987. A-type granites: geochemical characteristics, discrimination and petrogenesis. Contributions to Mineralogy and Petrology $95,407-419$. 